Article

\title{
Sustainable Biodiesel Production by Transesterification of Waste Cooking Oil and Recycling of Wastewater Rich in Glycerol as a Feed to Microalgae
}

\author{
Ombretta Paladino*(D) and Matteo Neviani (D)
}

check for updates

Citation: Paladino, O.; Neviani, M. Sustainable Biodiesel Production by Transesterification of Waste Cooking Oil and Recycling of Wastewater Rich in Glycerol as a Feed to Microalgae. Sustainability 2022, 14, 273. https:/ / doi.org/10.3390/su14010273

Academic Editor: Agostina Chiavola

Received: 23 November 2021

Accepted: 23 December 2021

Published: 28 December 2021

Publisher's Note: MDPI stays neutral with regard to jurisdictional claims in published maps and institutional affiliations.

Copyright: (C) 2021 by the authors. Licensee MDPI, Basel, Switzerland. This article is an open access article distributed under the terms and conditions of the Creative Commons Attribution (CC BY) license (https:// creativecommons.org/licenses/by/ $4.0 /)$.
DICCA-Department of Civil, Chemical and Environmental Engineering, University of Genoa, Via Opera Pia 15, 16145 Genoa, Italy; matteo.neviani@gmail.com

* Correspondence: paladino@unige.it

\begin{abstract}
The amount of solid and liquid organic waste and wastewater is continuously increasing all over the world. The necessity of their reuse and recycling is, therefore, becoming more and more pressing. Furthermore, the limited fossil fuel resources, in conjunction with the need to reduce greenhouse gas emissions, advocate the production of renewable fuels. In this work, we analyze a sustainable second-generation process to produce biodiesel by transesterification of waste cooking oil, coupled with a third-generation process in cascade for recycling the incoming wastewater. Since this latter is rich in glycerol, it is used as a feed for microalgae, from which oil can be extracted and added to the waste cooking oil to further produce biodiesel and close the cycle. We studied the influence of different factors like temperature, catalyst load, and reactants ratio on the kinetics of transesterification of the waste oil and estimated the kinetic parameters by different kinetic schemes. The obtained values of activation energies and preexponential factors at chosen conditions of $T=60^{\circ} \mathrm{C}$ and catalyst load of $0.6 \% w / w$ in methanol are: $E_{a, \text { direct }}=35,661 \mathrm{~J} \mathrm{~mol}^{-1}, E_{a, \text { reverse }}=72,989 \mathrm{~J} \mathrm{~mol}^{-1}, k_{0, \text { direct }}=9.7708\left[\mathrm{dm}^{3} \mathrm{~mol}^{-1}\right]^{3} \mathrm{~min}^{-1}$, and $k_{0, \text { reverse }}=24,810\left[\mathrm{dm}^{3} \mathrm{~mol}^{-1}\right]^{3} \mathrm{~min}^{-1}$ for the global fourth-order reversible reaction scheme and $E_{a}=67,348 \mathrm{~J} \mathrm{~mol}^{-1}$ and $k_{0}=2.157 \times 10^{9} \mathrm{~min}^{-1}$ for the simplified pseudo-first-order irreversible reaction scheme; both in strong agreement with literature data. Furthermore, we designed very efficient conditions for discontinuous and continuous operating mode, both at lab-scale and pilot-scale. The quality of the biodiesel produced from waste cooking sunflower oil is compared with that of biodiesel produced by different kinds of virgin vegetable oils, showing that the former possesses acceptable quality standards (Cetane number $=48$ and LHV $=36,600 \mathrm{~kJ} \mathrm{~kg}^{-1}$ ). Finally, the recycling of wastewater rich in glycerol as a nutrient for mixotrophic microalgae nurturing is discussed, and microalgae growing kinetics are evaluated $\left(\mathrm{k}_{1}\right.$ about 0.5 day $\left.^{-1}\right)$, endorsing the possibility of algae extraction each $4-5$ days in a semi-continuous operating mode. The experimental results at the pilot scale finally confirm the quality of biodiesel, and the obtained yields for a two-stage process prove the competitiveness of this sustainable process on the global market.
\end{abstract}

Keywords: waste oil; biodiesel; transesterification; kinetics; recycle; microalgae; wastewater; glycerol

\section{Introduction}

Fossil fuels are non-renewable resources, and consequently, they will last for a limited period of time. The bounded fossil fuel resources, along with the need to reduce Green House Gas (GHG) emissions, were in the past a major impulse to the development of alternative fuels, that can be partially or totally derived by organic waste. Historically, political turmoil in the Middle East or natural disasters (such as Hurricane Katrina) have resulted in shortages of petroleum products and accompanying spikes in prices. Even if political and production issues could be remedied, recent estimates suggest that the current rates of consumption will result in the depletion of oil and natural gas reserves in roughly 
50 years and less than a century and a quarter for the coal ones [1]. As suggested by the demise of the peak oil theory by Campbell and Laherrère [2], such estimates have to be used only as static references, since the capacity to extract fossil fuels varies continuously over time and the consumption levels may rise and fall. Encouraging signs are provided by the plateauing of the world coal production in 2013, while crude oil should have reached peak demand in 2019 [3].

In 2015, the involved Parties pledged to restrict global warming, committing to put in the efforts for limiting the temperature increase to $1.5^{\circ} \mathrm{C}$ and maximum $2{ }^{\circ} \mathrm{C}$ with respect to pre-industrial times [3]. As carbon dioxide $\left(\mathrm{CO}_{2}\right)$ is the main contributor to GHGs in terms of quantity, the focus is now on both power generation and transport sector. Since 1990, the emissions linked to the transport sector have increased by more than $50 \%$, earning the primacy for the fastest growing $\mathrm{CO}_{2}$ source and weighing for $25 \%$ of the total emissions of carbon dioxide from the combustion of fuels [4]. As a result, increased attention has been given to biofuels, such as biodiesel, that can be used as an alternative fuel in compression-ignition engines. The use of biofuels, along with the more widespread adoption of electric vehicles, embody the pathway for the necessary paradigm shift needed to bring sustainability to the transport industry; furthermore, in sectors like marine transport, aviation, and heavy freight, biofuels are currently seen as the only realistic and practical alternative to fossil fuels [5].

The production of biodiesel from renewable resources, such as vegetable oils and animal fats, makes it biodegradable and non-toxic. Moreover, it contributes to the reduction of $\mathrm{CO}_{2}$ emissions, because it comprises a closed carbon cycle [6]. Vegetable oils can be considered a good alternative fuel, because of their renewable nature and environmental benefits [7].

Despite all the advantages, the use of vegetable oils as a fuel inevitably has some drawbacks. The direct use in internal combustion engines is problematic because vegetable oils have a higher viscosity than diesel fuel and lower volatility, so they do not burn completely and form deposits in the fuel injectors of diesel engines. According to the literature, there are five ways to reduce these problems: the blending of vegetable oil and diesel, thermal cracking (pyrolysis), micro-emulsions, esterification, and transesterification [8]. Esterification and transesterification reactions are the most favored reaction pathways to produce biodiesel [9].

Biodiesel is a highly biodegradable fuel in water as well as in soil and a great part of it, under aerobic or anaerobic conditions, is mineralized in 28 days at most [10]. It is also a carbon-free fuel, as the plants that serve as raw material for its production absorb more carbon than that which is released during the burning of this biofuel [11]. Moreover, when biodiesel is burned in diesel engines, the emissions of hydrocarbons, carbon monoxide, particulate matter, and sulfur dioxide are reduced except for nitrogen oxides, the emission of which increases due to the oxygen content of biodiesel [12].

Studies of diesel engines powered by biodiesel published by the Health and Safety Institute shows that fine particulate (PM10) is reduced by $58 \%$ with a decrease of $76 \%$ of the carbonaceous moiety (soot), which is its most harmful one since not only it is the more absorbable during breathing but it also cannot be traced by catalytic filters. Carbon monoxide is reduced by $58 \%$ as well at high loads and aromatic compounds undergo a decrease of $68 \%$, thus reducing the risk of cancer, whilst there were no significant changes as regards the other unregulated pollutants.

The production and trade of biofuels have increased in recent years, to meet global demand for renewable fuels. The major participants in the liquid biofuels trade (ethanol more than biodiesel) are Brazil, China, the USA, India, and the European Union (EU) with France and Germany in the lead $[5,13]$.

To increase the biodiesel trade, the governments promulgated different promoting policies and incentives. Among the EU's policies, the Renewable Energy Directive (RED), which caused a high demand for biodiesel imports in the EU, its 2018 evolution, the RED II and the EU's Fuel Quality Directive, stating the requirements and quality standards for 
renewable fuel use, can be cited [14]. RED requirements also define the sources of biomass that are considered sustainable (direct/indirect land use in producing biofuels). Current legislation in the EU also proposes limits on transportation energy that can originate from crop-based biofuels and restrictions on these limits are increasing: the RED II introduces a cap on conventional biofuels gradually diminishing to $3.8 \%$ in 2030 from the 2021 limit of $7 \%$ and a minimum share of $6.8 \%$ by 2030 of advanced biofuels increasing from the $1.5 \%$ specified for 2021 [15].

For all these reasons it is necessary to move to other sustainable biomass for biofuels production, not in competition with other resources, and a possible solution is to use organic waste. Since biodiesel is made by simple alkyl monoesters of long-chain fatty acids, it can be produced from waste vegetable oils.

Vegetable oils, including waste oils from cooking, generally referred to as Straight Vegetable Oils (SVO) can be burned directly as a fossil diesel substitute for energy production but due to their high viscosity, their use leads to poor efficiency in combustion, incomplete combustion, carbonization on rings and injectors, and poor atomization of the biofuel. For all these reasons the transesterification process is used, allowing the transformation of the initial triglyceride (oil) into esters (biodiesel) and glycerol (byproduct), using alcohol as reactant plus a catalyst, usually a strong alkaline like potassium or sodium hydroxide. The quality of the produced biodiesel depends on the quality of the initial vegetable oil, i.e., on the fatty acids attached to the glycerol and composing the triglyceride, and on the impurities generated during cooking, if waste frying oils are used.

As second-generation processes are used for the production of biofuels, new issues related to their sustainability hide when any by-products or waste generated cannot easily be reused or recycled. Currently, glycerol occupies an almost saturated market, a fact resulting in a continued decline of its price and thus directly affecting the biodiesel production cost. This trend will not cease as more biodiesel production facilities begin production [16] unless other ways of reusing this by-product are found. Among them, pyrolysis, gasification, reforming, photocatalysis, and bioconversion are the most investigated ones.

Wastewater coming out of the biodiesel washing process still contains glycerol and methanol; one possibility of recycling them consists in using them as feed to photobioreactors for the cultivation of microalgae, from which oil can be extracted and exploited yet again for transesterification.

Different strains of microalgae, including Chlorella vulgaris, have shown high tolerance to wastewater with high nutrient concentration [17]. Wastewater containing glycerol was used in heterotrophic nurturing of Chlorella vulgaris [18,19], resulting in high yields [20]. Paladino and Neviani [21] conducted experimental activity on Chlorella $v$. using synthetic wastewater with the addition of glycerol at concentrations of 4-15 mg L ${ }^{-1}$ and flue-gas, obtaining interesting growing kinetics, such as to suggest the integration with the biodiesel production process.

In this work, we propose a sustainable process to produce biodiesel by transesterification of waste cooking oil (second generation), in which wastewater in exit from the transesterification stage is completely recycled and used as a feed for microalgae, from which oil is extracted and added to the waste cooking oil to produce again biodiesel (third generation), closing the cycle. We compared the quality of the biodiesel produced from waste cooking oil with that of biodiesel produced by different kinds of virgin vegetable oils, showing that the former can possess high-quality standards, comparable to those of biodiesel produced by virgin oils. We also estimated the kinetics of our production process and the best operating conditions in discontinuous and continuous operating modes. Finally, the recycling of wastewater rich in glycerol as a nutrient for mixotrophic microalgae nurturing is discussed and the estimated microalgae growing conditions are reported.

These represent key data, necessary to gauge the competitiveness of this biodiesel production process on the global market. 


\section{Materials and Methods}

\subsection{Transesterification of Vegetable Oils}

Transesterification of vegetable oils consists of a set of organic reactions where a triglyceride (ester, TG) is transformed into another ester by reacting with alcohol (alcoholysis of carboxylic esters [22]) and in presence of a catalyst, usually a strong acid or base. The final product is a mixture of fatty acids mono alkyl esters (FAME) plus glycerol (G) [23]. Transesterification is an equilibrium reaction and the transformation occurs essentially by mixing the reactants and the catalyst. The overall process can be considered as a sequence of three consecutive and reversible reactions, in which mono-glycerides (MG) and di-glycerides (DG) are formed as intermediates [24]. A general reaction scheme using methanol (M) is reported in Figure 1. The global reaction scheme (Figure 2) requires a 1:3 TG:M molar ratio; however, an excess of alcohol is required to increase yields.

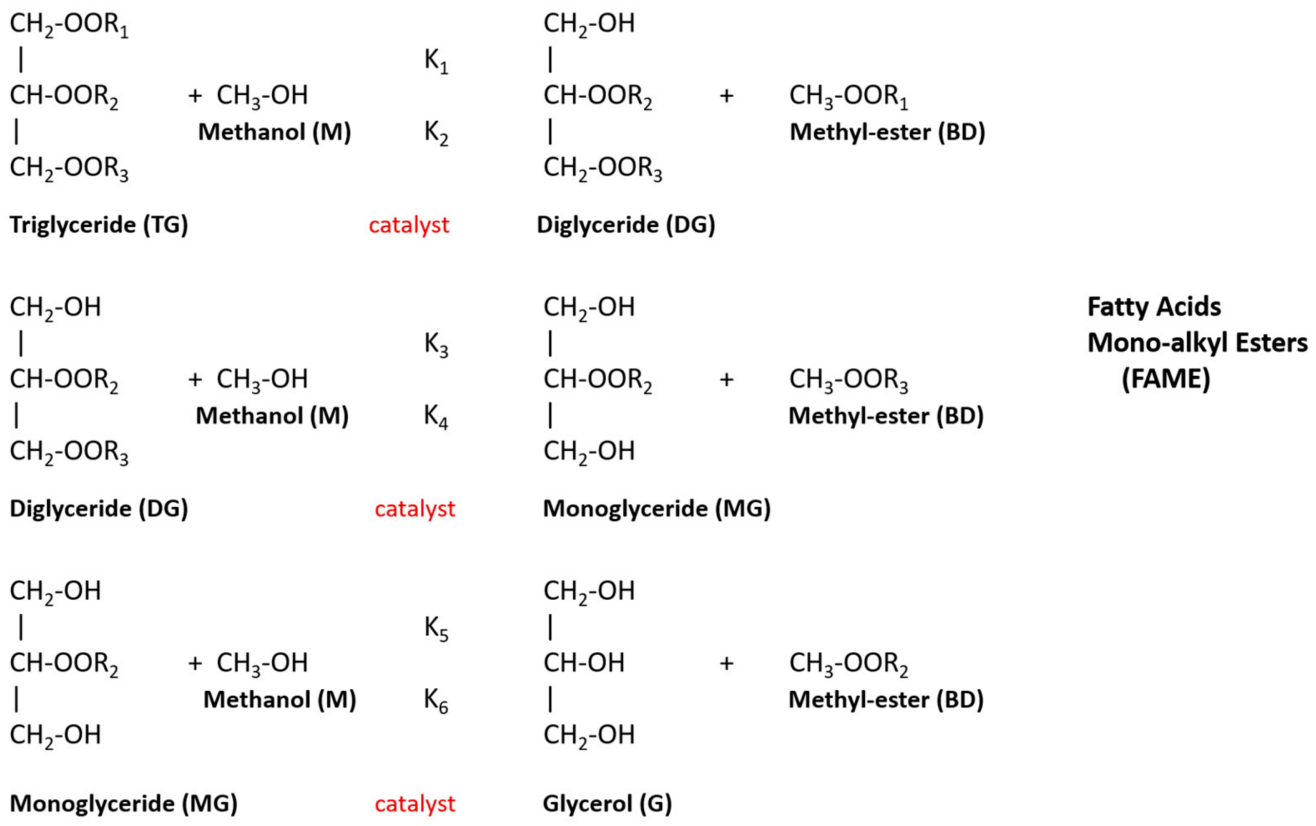

Figure 1. Transesterification of vegetable oils: Series reaction scheme.

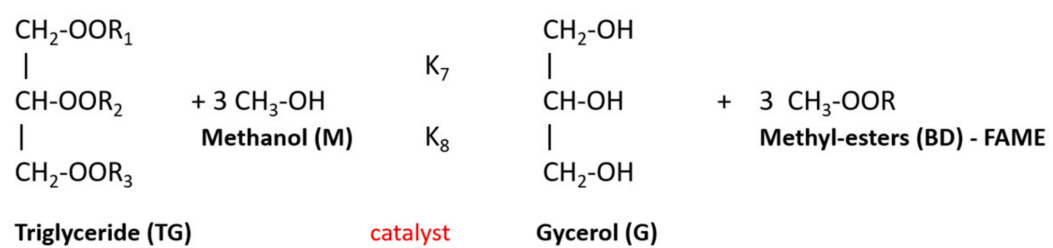

Figure 2. Transesterification of vegetable oils: Global reaction scheme.

The type of catalyst (acid or alkaline), waste oil/alcohol molar ratio, temperature, purity of the reactants (mainly water content), and initial free fatty acid content are the main factors influencing the transesterification process.

Acid-catalyzed transesterification of vegetable oils uses BrØnsted acids, preferably sulfonic and sulfuric acids [25]. Even if yields can reach high values, reaction time is still very high also at a temperature greater than $373 \mathrm{~K}$ [26].

Even if excess alcohol increases biodiesel formation, on the other hand, it makes it difficult to separate glycerol from the desired product. Consequently, the TG to alcohol ratio must be optimized, depending on the other factors. Acid-catalyzed transesterification should be carried out in the relative absence of water, to avoid the competitive formation of carboxylic acids which reduce the yields in FAME. 
Alkali-catalyzed transesterification of vegetable oils uses alkaline metal alkoxides [27] such as $\mathrm{CH}_{3} \mathrm{ONa}$, with yields reaching $98 \%$ and half an hour reaction time, and alkaline metal hydroxides [28] such as $\mathrm{KOH}$ and $\mathrm{NaOH}$, as well as sodium or potassium carbonates [29]. The kinetics are faster than the corresponding acid-catalyzed ones and alkaline catalysts are usually less corrosive than acid-catalysts. In addition, alkali-catalyzed transesterification requires a relative absence of water in the reactants. Anyway, water is produced by the reaction of the hydroxide with alcohol and its presence gives rise to hydrolysis of some of the produced FAME, with consequent soap formation. This undesirable saponification reaction reduces the ester yields and makes considerably more difficult the recovery of the glycerol due to the formation of emulsions [26]. Soap formation is reduced by the use of potassium carbonate at a molar fraction of 2-3\% [29], due to the formation of bicarbonate instead of water, which does not hydrolyze esters.

Untreated biodiesel contains impurities such as free glycerol, soaps, metals, free fatty acids, catalysts, water, and glycerides. The high impurities level can reduce the engine life. Table 1 shows each impurity effect.

Table 1. Effects of impurities on biodiesel and engines.

\begin{tabular}{|c|c|}
\hline Impurity & Effect \\
\hline Water & Oxidation, corrosion, and bacteriological growth (filter blockage). \\
\hline Glycerol & $\begin{array}{c}\text { Deposits in the injectors (carbon residue), high viscosity, crystallization, } \\
\text { settling problems. }\end{array}$ \\
\hline Methanol & $\begin{array}{l}\text { Low values of density and viscosity, low flash point (transport, storage, and } \\
\text { usage problems), corrosion of } \mathrm{Al} \text { and } \mathrm{Zn} \text {. }\end{array}$ \\
\hline Soap & $\begin{array}{c}\text { Deposits in the injectors (carbon residue), filter blockage (sulfated ashes), } \\
\text { engine weakening. }\end{array}$ \\
\hline
\end{tabular}

There are generally two accepted methods for purifying biodiesel: wet and dry. The most traditional one is wet cleaning and it is widely used to remove contaminants as alcohol in excess, catalyst, and soap [30]. However, the water-washing process has several disadvantages, such as yield loss in the effluent, and high soap levels that cause emulsification [31]. The emulsion can occur when the reaction is not complete and residual triglycerides remain inside the mixture allowing the bonding of glycerine molecules to the esters portion. These tend to be not very soluble in water and thicken up, thus creating a creamy-like textured emulsion.

After washing, biodiesel is dried by vacuum flash drying or it can dry when left into settling tanks [32].

\subsection{Transesterification of Waste-Cooking Oils}

The proposed process at the pilot scale is a two-stage sodium hydroxide-catalyzed transesterification. The waste cooking oil (fried sunflower oil) was collected by the Campus canteen. The other three uncooked oils were used for comparison to produce biodiesel with the same process: sunflower oil, olive oil, and rapeseed oil.

Previous experimental tests using both methanol and ethanol suggested the former as the most promising reactant in terms of yields in biodiesel, so the proposed study was carried out with methanol. Experimental tests were performed by following the classical scale-up steps for studying catalyzed reactions. They consist in:

1. Study of the reaction rate at lab scale in discontinuous operating mode, to find the main factors influencing kinetics, compute conversion and yields, estimate kinetic parameters, and choose the optimal values of the main factors (reactants ratio, catalyst load, temperature) influencing the process;

2. Verification of the quality of products and by-products, analysis of the produced waste and wastewater, identification and test of possible processes to recycle and/or reuse by-products and waste; 
3. Experimental tests at pilot-scale in discontinuous operating mode, by considering all the other phenomena influencing kinetics, as heat and mass transfer;

4. Experimental tests and simulation at pilot-scale in continuous operating mode, to optimize residence times and yields.

Regarding step 4, only simulations were performed and results will be presented elsewhere.

\subsubsection{Lab-Scale}

The mixing and pre-heating of the chosen quantities of alcohol and granular $\mathrm{NaOH}$ catalyst were carried out in a flat bottom flask connected to a bulb (Allihn) condenser, and mixed by magnetic stirring until a perfectly homogeneous blend in the liquid phase was obtained. A conical flask (Erlenmeyer Pyrex ${ }^{\circledR}$ ) containing oil was posed on the hotplate of another magnetic stirrer and heated until the temperature, constantly measured with a calorimetric sensor, reached the chosen process value; then the mixture of methanol plus catalyst was slowly added to the heated oil and mixed for the chosen reaction time (maximum time equal to $1 \mathrm{~h}$ ). Samples were collected at different step-times. At the chosen final time the mixture was sent to a separation funnel (decanter, with residence time equal to $5 \mathrm{~h}$ ) (see Figure 3).

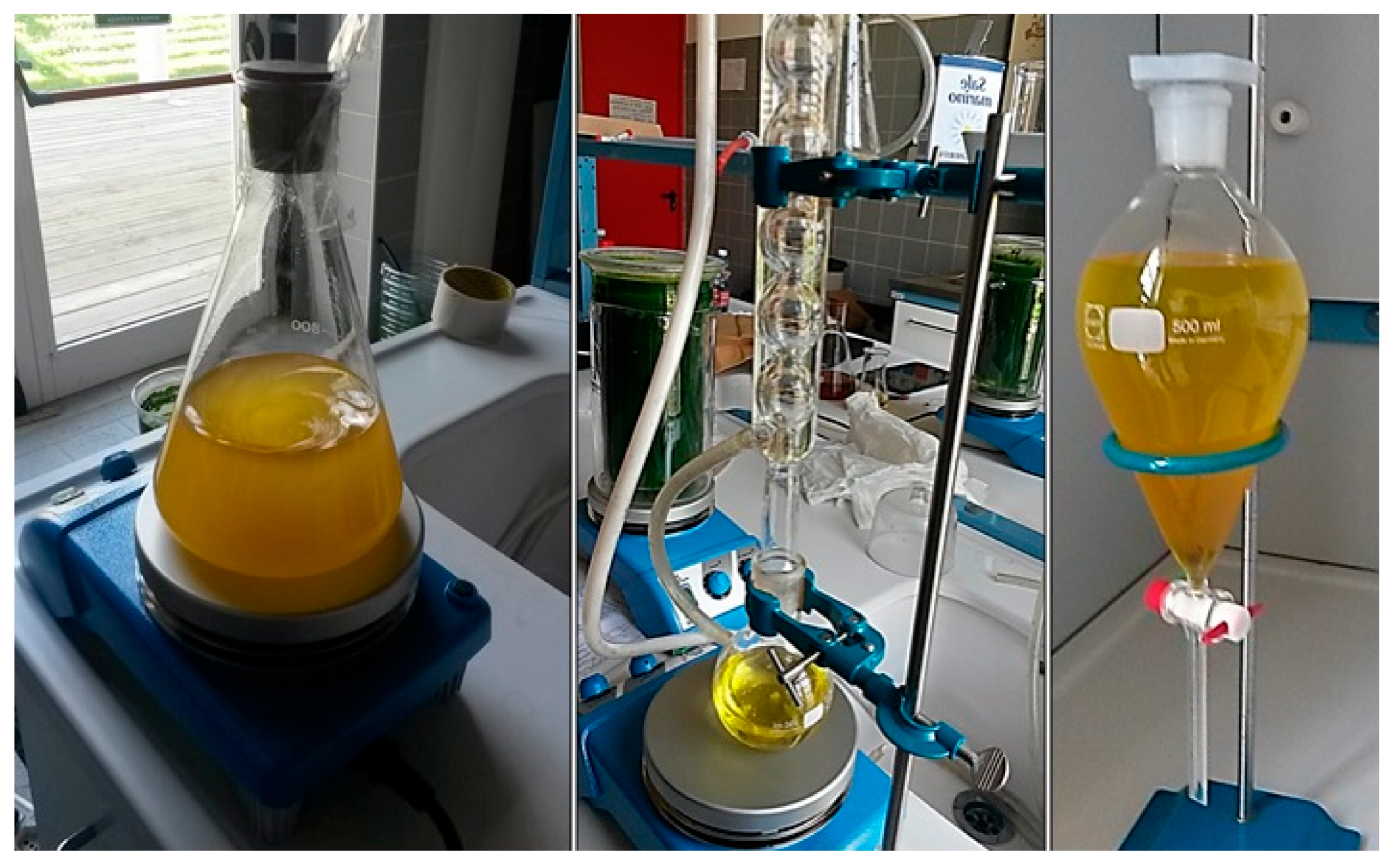

Figure 3. Lab-scale biodiesel production. Waste oil (left), catalyst and alcohol (center), decanter (right).

Purification of the biodiesel was carried out by a bubble washing technique. At first, the $\mathrm{pH}$ of biodiesel extracted from the decanter was measured. Then the procedure of bubble washing started by slowly adding dilute acetic acid to neutralize the $\mathrm{pH}$ of the ester so as to prevent emulsion formation. The apparatus used for the purification process at lab-scale was an aquarium air pump, responsible for creating bubbles at a rate of about 10 bubbles per second through a sponge-diffuser, plunged in the flat-bottomed conical flask (or separation funnel) containing biodiesel and water/acetic acid solution.

Since the water solution density is higher than that of biodiesel, the water stays at the bottom of the washing tank, where the bubbles sprout out from the diffuser. Bubbles rise, first crossing water and then biodiesel. Every bubble remains covered by a thin film of water and raises passing through biodiesel, washing it on the way. When the bubble comes to the surface it explodes and leaves a small drop of water that returns to the bottom, crossing again the biodiesel and washing it again [33]. 


\subsubsection{Pilot-Scale}

Waste oil was pre-treated by a full-flow oil filter. Even if oil pretreatment is very important in base catalyzed transesterification (being this process highly sensitive to initial FFAs composition), expensive pretreatment processes such as distillation or acid preesterification are not suitable in this context. Moreover, the possibility of adding the oil extracted from the microalgae to the waste oil will produce a blend of high FFA feedstock with a lower one, so reducing the possibility of initial saponification reactions.

We adopted two stainless steel stirred reactors (AISI 304) of volume $V=15 \mathrm{~L}$ at low mixing velocity (60-120 rpm) for the first- and second-stage transesterification process; one stainless steel mixer (AISI 304) of $V=5 \mathrm{~L}$ at high stirring velocity (1200 rpm) to prepare the catalyst/methanol blend and two stainless steel decanters of $V=20 \mathrm{~L}$ (see Figure 4). Velp Scientifica PW overhead stirrers were used. The heating system of the transesterification reactors was made by resistive wires, electrically insulated from external tubular sheaths (mineral insulation by magnesium oxide) surrounded by insulating material wrapped around the reactor. The tubular sheaths had excellent thermal conductivity, in order to assure high heat transfer to the reactor wall.

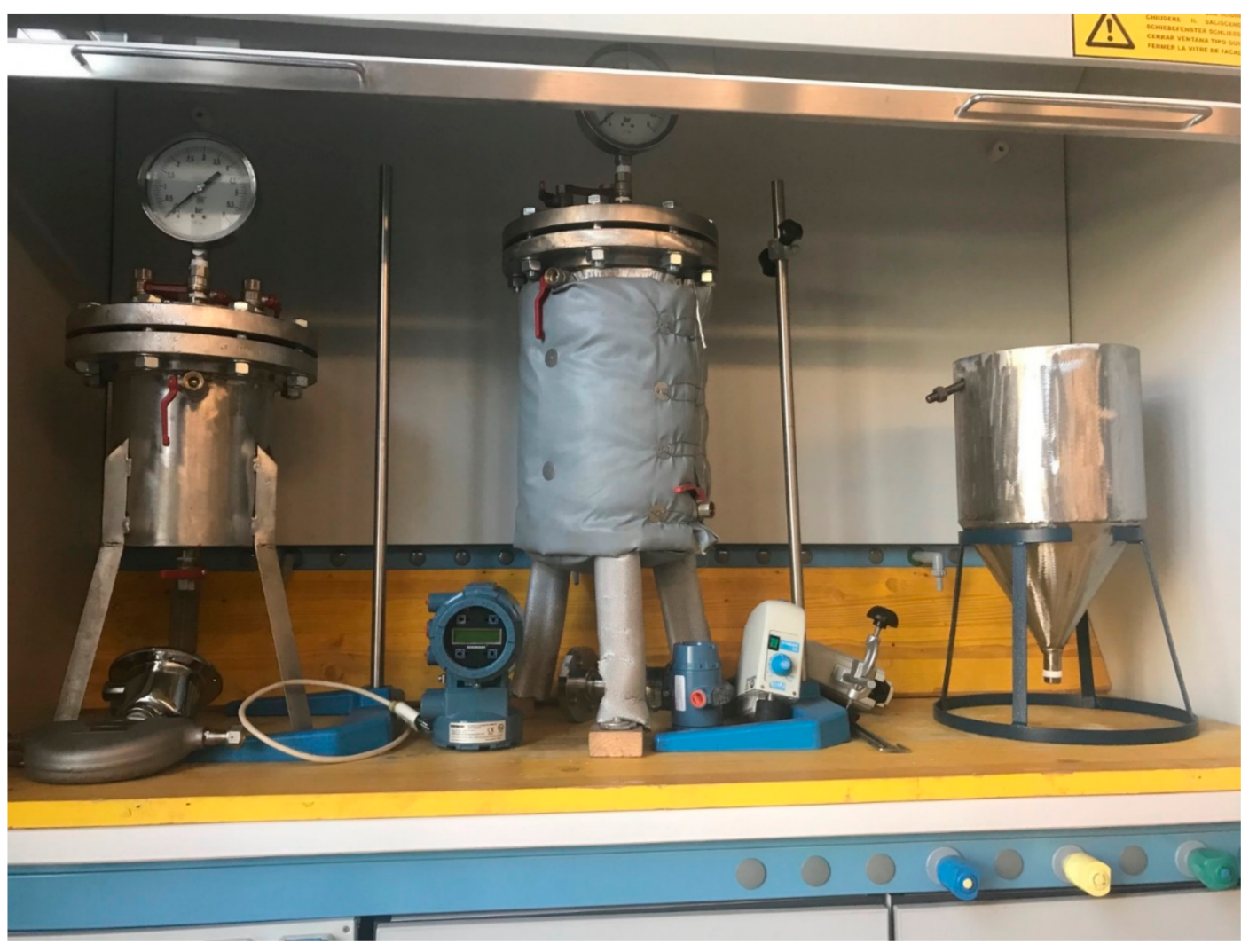

Figure 4. Pilot-scale biodiesel production. Mixer (left), transesterification reactor (center), decanter (right).

The products in exit from the first TE reactor were sent to the first decanter while the final product in exit from the second stage was purified by bubble washing inside the second decanter, operated as washing/separation unit. $\mathrm{pH}$ was adjusted by manipulating a Gilson Minipuls 3 peristaltic pump (through the PXI station) to dose dilute acetic acid.

\subsection{Wastewater Treatment by Microalgae}

At lab-scale, microalgae of the Chlorella vulgaris species were nurtured in glass stirred tank reactors of $V=2.5 \mathrm{~L}$, and internal diameter of $0.120 \mathrm{~m}$, mixed by Velp Scientifica PW overhead stirrers, at $100 \mathrm{rpm}$ (radial impeller with a diameter equal to $0.080 \mathrm{~m}$ ). The reactors had clamped tops with three nozzles for probes introduction: $\mathrm{pH}$, temperature 
$(T)$, conductivity $(C)$, and dissolved oxygen $(D O)$ were online acquired. The operation could be managed in fed-batch and wastewater in exit from transesterification was inserted by controlled peristaltic pumps (Gilson Minipuls 3) so as microalgae extraction could be cyclically operated.

At the pilot scale, we used external loop airlift reactors made by polymethyl methacrylate (PMMA). Each reactor had a total volume of $10.5 \mathrm{~L}$, with the downcomer diameter equal to $0.110 \mathrm{~m}$ and the riser diameter equal to $0.050 \mathrm{~m}$. Collectors (diameter $=0.050 \mathrm{~m}$ ) were made of poly-vinyl-chloride. Probes for $\mathrm{pH}, T, C$, and $D O$ measurements were inserted in the midsection of the lower collector and online measures were managed by MEMO HQ Scada system [34]. Air was sparged at the bottom of the riser by a stainless steel diffuser. Inlet wastewater flowrate and extracted microalgae flowrate were controlled and it was possible to operate in both fed-batch and semi-continuous mode.

Details about photobioreactors scale-up can be found in Paladino and Neviani [35].

In the present paper, we only report results on the capability of the microalgae to exploit wastewater in exit from the transesterification stage to grow in mixotrophic conditions and on their growing kinetics. Other insights about the optimal operating conditions inside the photobioreactors can be found in [21].

\subsection{Instrumentation}

\subsubsection{Transesterification of Waste Oil}

At the lab scale, samples were collected every five minutes during the batch transesterification reaction and analyzed to estimate kinetics. At the pilot scale, only the final product in exit from the first and the second stages at the designed residence time was analyzed.

Samples were analyzed by Trace-Ultra GC (Agilent 19091S-433 column) and TSQ 8000 MS by Thermo Fischer Scientific following EU EN 14214 (test methods EN 14103, EN 14105 for FAMEs determination, EN ISO 5165 for cetane number; specifics and conditions can be found in the Supplementary Material, Table S1). Before proceeding with the analysis, samples were prepared by operating cold methylation, weighing $400 \mathrm{mg}$ sample $+6 \mathrm{~mL}$ hexane $+0.25 \mathrm{~mL}$ of methanolic $\mathrm{KOH}$. This operation guarantees that all the peaks are methyl esters.

Low Heating Value was measured by a semi-automatic bomb calorimeter (mod C200 Basic, IKA).

The research laboratory is quality certified UNI EN ISO 9001: 2008 and Environmental quality certified UNI EN ISO 14001: 2015. The analytical chemistry laboratory where samples are analyzed is certified UNI CEI EN ISO/IEC 17025:2018 and instrumentation is managed under UNI EN ISO 10012:2004.

\subsubsection{Wastewater Recycling in Microalgae Cultivation}

Online measures of the main parameters inside the reactors were acquired by $B \& C$ Electronics series 7685 Microcontrollers and related probes. Flowrates were manipulated by the PXI National Instrument system plus Labview. Gilson Minipuls 3 and Welko WP1100 peristaltic pumps were respectively used at the lab and pilot scale.

The microalgae concentration was offline daily acquired by measuring the absorbance of samples at different wavelengths (430, 480, 650, and $680 \mathrm{~nm}$ ). Details about calibration curves can be found in [35]. A Hach DR-6000 UV-VIS spectrophotometer was used, while the wastewater composition was measured by both GC and UV-VIS spectrophotometers.

\section{Results}

\subsection{Experiments at the Lab Scale: Kinetics}

The experimental campaign at the lab scale was designed by considering four factors at different levels.

- Factor N.1: type of oils, at four levels (waste sunflower oil, uncooked sunflower, olive, and rapeseed oil);

- Factor N.2: molar reactants ratio, at three levels (oil/alcohol = 1:3, 1:5, 1:7);

- Factor N.3: temperature, at four levels $\left(20^{\circ} \mathrm{C}, 50^{\circ} \mathrm{C}, 60^{\circ} \mathrm{C}, 70^{\circ} \mathrm{C}\right)$; 
- $\quad$ Factor N.4: catalyst load at three levels $(0.3 \%, 0.6 \%, 1.2 \% w / w$ in methanol).

Some runs were eliminated due to expected lack of information on kinetics and a total of 78 runs were carried out.

Mixing is another important factor. For this reaction a slow reaction rate at initial times was observed, followed by a sudden increase for about 40-60 min, followed again by a rate decrease as the reaction approaches equilibrium. At the initial time, a two-phase L-L system is present, with a diffusion-controlled mechanism; as time passes, the formed methyl esters act as solvents for the remaining reactants and the system can be considered as a homogeneous liquid phase under a kinetic-controlled mechanism. A good mixing reduces the period of mass transfer control to less than one minute. All the experiments were conducted at Reynolds number Re greater than 8000, and this value was kept during the scale-up.

The concentration of biodiesel was measured every $5 \mathrm{~min}$ in order to estimate the kinetic constants. Tables 2 and 3 show some of the collected data.

Table 2. Methyl-esters (BD) concentration $\left(\mathrm{mol} \mathrm{dm}^{-3}\right)$ versus time at different molar reactants ratio, fixed temperature $\left(T=60^{\circ} \mathrm{C}\right)$, and fixed catalyst load $(0.6 \% w / w)$.

\begin{tabular}{|c|c|c|c|c|c|c|c|}
\hline TG:M & $5 \mathrm{~min}$ & $10 \mathrm{~min}$ & $15 \mathrm{~min}$ & $20 \mathrm{~min}$ & $30 \mathrm{~min}$ & $40 \mathrm{~min}$ & $60 \mathrm{~min}$ \\
\hline $1: 3$ & 0.35 & 0.45 & 0.51 & 0.52 & 0.55 & 0.58 & 0.64 \\
\hline $1: 5$ & 1.50 & 1.72 & 1.85 & 1.92 & 1.97 & 1.98 & 2.01 \\
\hline $1: 7$ & 1.80 & 1.95 & 2.00 & 2.10 & 2.15 & 2.15 & 2.16 \\
\hline
\end{tabular}

Table 3. Methyl-esters (BD) concentration $\left(\mathrm{mol} \mathrm{dm}^{-3}\right)$ versus time at different temperatures, fixed molar reactants ratio (TG:M $=1: 5)$, and fixed catalyst load $(0.6 \% w / w)$.

\begin{tabular}{|c|c|c|c|c|c|c|c|}
\hline$T$ & $5 \mathrm{~min}$ & $10 \mathrm{~min}$ & $15 \mathrm{~min}$ & $20 \mathrm{~min}$ & $30 \mathrm{~min}$ & $40 \mathrm{~min}$ & $60 \mathrm{~min}$ \\
\hline $20^{\circ} \mathrm{C}$ & 0.15 & 0.21 & 0.35 & 0.50 & 0.65 & 0.80 & 1.15 \\
\hline $50{ }^{\circ} \mathrm{C}$ & 1.35 & 1.60 & 1.80 & 1.88 & 1.92 & 1.98 & 1.98 \\
\hline $70{ }^{\circ} \mathrm{C}$ & 1.90 & 2.08 & 2.10 & 2.15 & 2.15 & 2.16 & 2.16 \\
\hline
\end{tabular}

By adopting the reaction scheme of Figure 1, and defining the generation/consumption term for each component $i$ inside the reacting system as $r_{i}\left(\mathrm{~mol} \mathrm{dm}{ }^{-3} \mathrm{~s}^{-1}\right)$, the following molar balances can be written for the discontinuous reactor at the lab scale:

$$
\begin{gathered}
\frac{d[\mathrm{M}]}{d t}=r_{\mathrm{M}}=-k_{1}[\mathrm{TG}] \cdot[\mathrm{M}]+k_{2}[\mathrm{DG}] \cdot[\mathrm{BD}]-k_{3}[\mathrm{DG}] \cdot[\mathrm{M}]+k_{4}[\mathrm{MG}] \cdot[\mathrm{BD}]-k_{5}[\mathrm{MG}] \cdot[\mathrm{M}]+k_{6}[\mathrm{G}] \cdot[\mathrm{BD}] \\
\frac{d[\mathrm{DG}]}{d t}=r_{\mathrm{DG}}=k_{1}[\mathrm{TG}] \cdot[\mathrm{M}]-k_{2}[\mathrm{DG}] \cdot[\mathrm{BD}]-k_{3}[\mathrm{DG}] \cdot[\mathrm{M}]+k_{4}[\mathrm{MG}] \cdot[\mathrm{BD}] \\
\frac{d[\mathrm{MG}]}{d t}=r_{\mathrm{MG}}=k_{3}[\mathrm{DG}] \cdot[\mathrm{M}]-k_{4}[\mathrm{MG}] \cdot[\mathrm{BD}]-k_{5}[\mathrm{MG}] \cdot[\mathrm{M}]+k_{6}[\mathrm{G}] \cdot[\mathrm{BD}] \\
\frac{d[\mathrm{G}]}{d t}=r_{\mathrm{G}}=k_{5}[\mathrm{MG}] \cdot[\mathrm{M}]-k_{6}[\mathrm{G}] \cdot[\mathrm{BD}] \\
\frac{d[\mathrm{BD}]}{d t}=r_{\mathrm{BD}}=k_{1}[\mathrm{TG}] \cdot[\mathrm{M}]-k_{2}[\mathrm{DG}] \cdot[\mathrm{BD}]+k_{3}[\mathrm{DG}] \cdot[\mathrm{M}]-k_{4}[\mathrm{MG}] \cdot[\mathrm{BD}]+k_{5}[\mathrm{MG}] \cdot[\mathrm{M}]-k_{6}[\mathrm{G}] \cdot[\mathrm{BD}]
\end{gathered}
$$

A first simulation was carried out by using the kinetic data reported in [36] for transesterification of soybean oil at operating temperature equal to $50{ }^{\circ} \mathrm{C}$, and $\operatorname{Re}=6200$. The six unknown pre-exponential factors were computed by using the Arrhenius law (see Table 4) as

$$
k_{0, i}=k_{i}\left(\exp \left(-\frac{E_{A, i}}{R T}\right)\right)^{-1}
$$


Table 4. Kinetic values used for simulation.

\begin{tabular}{cccccc}
\hline $\begin{array}{c}\text { Kinetic Constant } \\
{\left[\mathbf{d m}^{\mathbf{3}} \mathbf{~ m o l}^{-\mathbf{1}} \mathbf{~ m i n}^{-1}\right]}\end{array}$ & \multicolumn{2}{c}{$\begin{array}{c}\text { Activation Energy } \\
{\left[\mathbf{J ~ m o l}^{-\mathbf{1}}\right]}\end{array}$} & \multicolumn{2}{c}{$\begin{array}{c}\text { Pre-Exponential Factor } \\
{\left[\mathbf{d m}^{\mathbf{3}} \mathbf{~ m o l}^{-\mathbf{1}} \mathbf{~ m i n}^{-\mathbf{1}} \mathbf{]}\right.}\end{array}$} \\
\hline$k_{1}$ & 0.050 & $E_{a, 1}$ & 55,000 & $k_{0,1}$ & $1.9 \times 10^{7}$ \\
\hline$k_{2}$ & 0.110 & $E_{a, 2}$ & 41,556 & $k_{0,2}$ & $3.35 \times 10^{5}$ \\
\hline$k_{3}$ & 0.215 & $E_{a, 3}$ & 83,094 & $k_{0,3}$ & $1.99 \times 10^{12}$ \\
\hline$k_{4}$ & 1.228 & $E_{a, 4}$ & 61,250 & $k_{0,4}$ & $4.43 \times 10^{9}$ \\
\hline$k_{5}$ & 0.242 & $E_{a, 5}$ & 26,866 & $k_{0,5}$ & $3.77 \times 10^{3}$ \\
\hline$k_{6}$ & 0.007 & $E_{a, 6}$ & 44,116 & $k_{0,6}$ & $5.36 \times 10^{4}$ \\
\hline
\end{tabular}

By looking at Table 4 , since $E_{a, 1}>E_{a, 2}$ and $E_{a, 3}>E_{a, 4}$, the first two reactions of the scheme reported in Figure 1 should be favored by high temperatures. By considering the pre-exponential factors $k_{0, i}$ constant with temperature, the kinetic constants at every level of the factor temperature in our experiments are calculated.

Other literature data were taken into consideration, as those reported in [37] for the transesterification of sunflower oil with ethanol and $\mathrm{NaOH}$ as the catalyst and those presented in [38] for sunflower methanolysis catalyzed by potassium hydroxide but parameters of [30] showed the best fit with our experimental data.

Simulations were carried out by recalling that vegetable oils are composed of triglycerides for about $96-98 \%$, and, since seed oils are mainly composed of oleic and linoleic acid, we supposed that the waste oil is only made by the ester between glycerol and oleic acid (glyceryl trioleate). Under this hypothesis (and supposing no degradation of waste oil during transesterification), it was possible to determine the initial number of moles of TG into the reactor, by considering the TG molar weight equal to $884 \mathrm{~g} \mathrm{~mol}^{-1}$ and its mean density around $910 \mathrm{~g} \mathrm{dm}^{-3}$. It was then possible to simulate the reaction inside the batch reactor at lab scale, in isothermal conditions, for all the different runs of the experimental campaign.

Some results are reported in Figures 5 and 6.

By looking at Figure 5, it can be observed that the increase in BD production is non-linear with the excess methanol and at molar ratios 1:10 almost all the TG is anyway reacted after $20 \mathrm{~min}$ (being $[\mathrm{TG}]_{0}=0.867 \mathrm{~mol} \mathrm{dm}^{-3}$, the maximum theoretical $[\mathrm{BD}]_{f}=2.601 \mathrm{~mol} \mathrm{dm}^{-3}$ ). The chosen operating condition is molar ratio TG:M=1:5. By observing Figure 6, an operating temperature of $60^{\circ} \mathrm{C}$ seems to assure a valid final biodiesel concentration for reacting times of about 30-40 min, paying attention that good mixing is assured. By taking into account energy savings and safety conditions (and excluding operating temperatures near the boiling temperature of methanol), this operating temperature seems to be a good choice for reacting times near to $40 \mathrm{~min}$. Figure $6 \mathrm{~b}$ shows the simulated reaction at molar TG:M=1:5, $T=60{ }^{\circ} \mathrm{C}$ and error bars of the measured biodiesel concentration. In this case, at $[\mathrm{TG}]_{0}=0.867 \mathrm{~mol} \mathrm{dm}^{3}$, the concentrations of waste oil and biodiesel after $30 \mathrm{~min}$ are respectively $[\mathrm{TG}]_{30}=0.149 \mathrm{~mol} \mathrm{dm}^{3}$ and $[\mathrm{BD}]_{30}=1.965 \mathrm{~mol} \mathrm{dm}^{3}$. This final condition corresponds to a conversion of TG equal to $84 \%$ and a yield of about $75 \%$. Comparing these simulated data with the experimental data of Table 2 reporting a $[\mathrm{BD}]_{30 \text {,exp }}=1.97 \mathrm{~mol} \mathrm{dm}^{3}$, it can be supposed that the kinetics parameters found by [36] for soybean oil at molar TG:M $=1: 6$ and $T=50^{\circ} \mathrm{C}$ can be successfully extended to roughly predict the transesterification of the sunflower cooking oil.

Anyway, the next step of the study was to estimate the kinetic parameters from the collected experimental data. Ref. [24] proposed to use of a pseudo-first-order kinetic scheme when the process is carried out in high excess alcohol conditions, reserving the second-order kinetics scheme of Figure 1 (three-reactions scheme plus shunt-reaction scheme) at lower excess alcohol. We estimated kinetics by adopting both the global reversible reaction scheme reported in Figure 2 and its simplification to a pseudo-first-order irreversible reaction. 


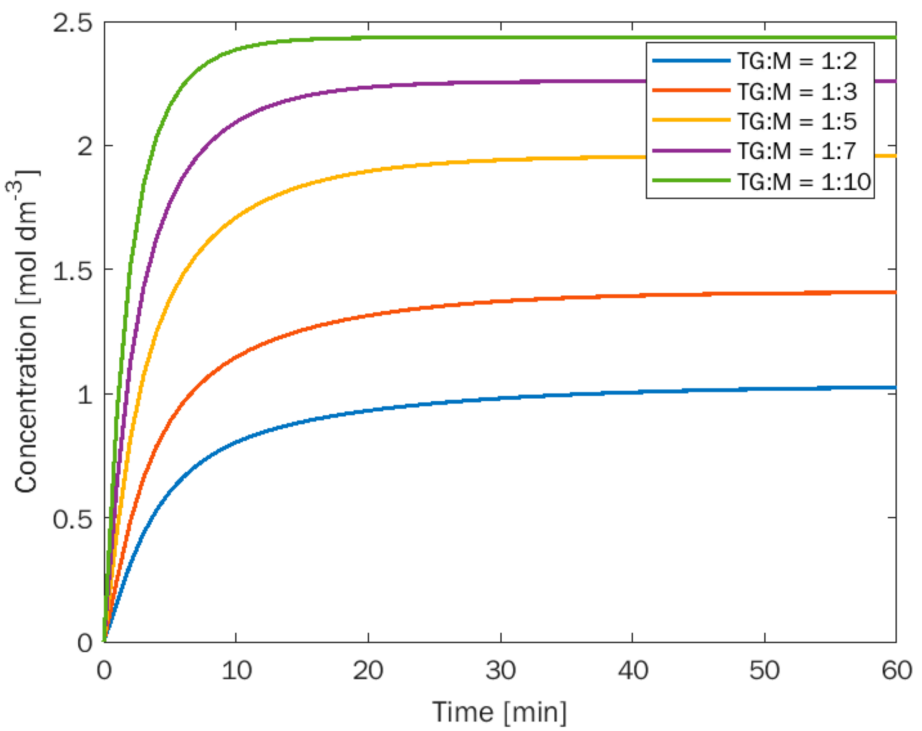

(a)

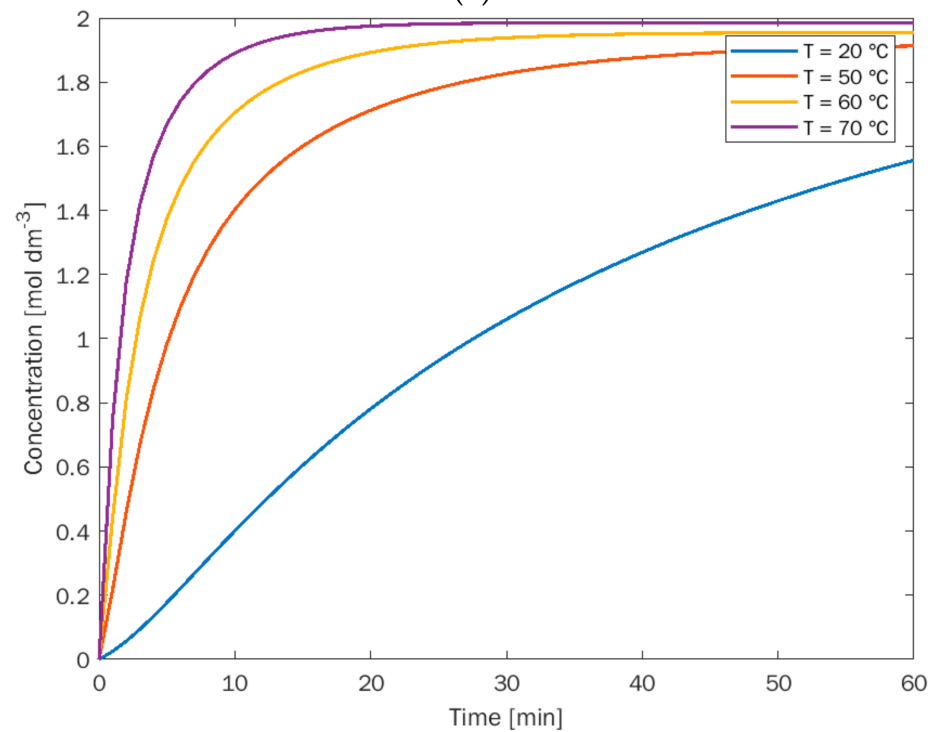

(b)

Figure 5. (a) Simulated biodiesel production from waste sunflower oil at changing reactants ratio, $T=60{ }^{\circ} \mathrm{C}$ and catalyst load $=0.6 \% w / w$. (b) Simulated biodiesel production from waste sunflower oil at changing reaction temperature, TG:M $=1: 5$ molar and catalyst load $=0.6 \% w / w$.

By considering the reaction scheme of Figure 2, we estimated the two constants $k_{7}$ and $k_{8}$ using the molar balances of the four components:

$$
\begin{aligned}
& \frac{d[\mathrm{TG}]}{d t}=-k_{7} \cdot[\mathrm{TG}] \cdot[\mathrm{M}]^{3}+k_{8}[\mathrm{G}] \cdot[\mathrm{BD}]^{3} \\
& \frac{d[\mathrm{M}]}{d t}=-3 k_{7}[\mathrm{TG}] \cdot[\mathrm{M}]^{3}+3 k_{8}[\mathrm{G}] \cdot[\mathrm{BD}]^{3} \\
& \frac{d[\mathrm{G}]}{d t}=k_{7}[\mathrm{TG}] \cdot[\mathrm{M}]^{3}-k_{8}[\mathrm{G}] \times[\mathrm{BD}]^{3} \\
& \frac{d[\mathrm{BD}]}{d t}=3 k_{7}[\mathrm{TG}] \cdot[\mathrm{M}]^{3}-3 k_{8}[\mathrm{G}] \cdot[\mathrm{BD}]^{3}
\end{aligned}
$$

to which two more equations (derived from experimental data) were added to solve the system. The former was the biodiesel concentration in time, obtained by fitting the measured biodiesel molar concentration at each fixed temperature with a time function of 
the kind $[\mathrm{BD}]_{t}=a t^{b}$ (results are shown in Figure 7). The latter is the van't Hoff equation, used to compute the equilibrium constant at different temperatures from the enthalpy literature data. The system was solved numerically at different reactants ratios, for each tested temperature and at the different catalyst loads for all the tested oils. Arrhenius equation was finally used to estimate $E_{a, 7}, E_{a, 8}, k_{0,7}$, and $k_{0,8}$ from the calculated couples $\left(k_{7} ; k_{8}\right)$ at the different temperatures. The estimated values for the waste sunflower oil are $E_{a, 7}=35,661 \mathrm{~J} \mathrm{~mol}^{-1}, E_{a, 8}=72,989 \mathrm{~J} \mathrm{~mol}^{-1}, k_{0,7}=9.7708\left[\mathrm{dm}^{3} \mathrm{~mol}^{-1}\right]^{3} \mathrm{~min}^{-1}$, and $k_{0,8}=24,810\left[\mathrm{dm}^{3} \mathrm{~mol}^{-1}\right]^{3} \mathrm{~min}^{-1}$.

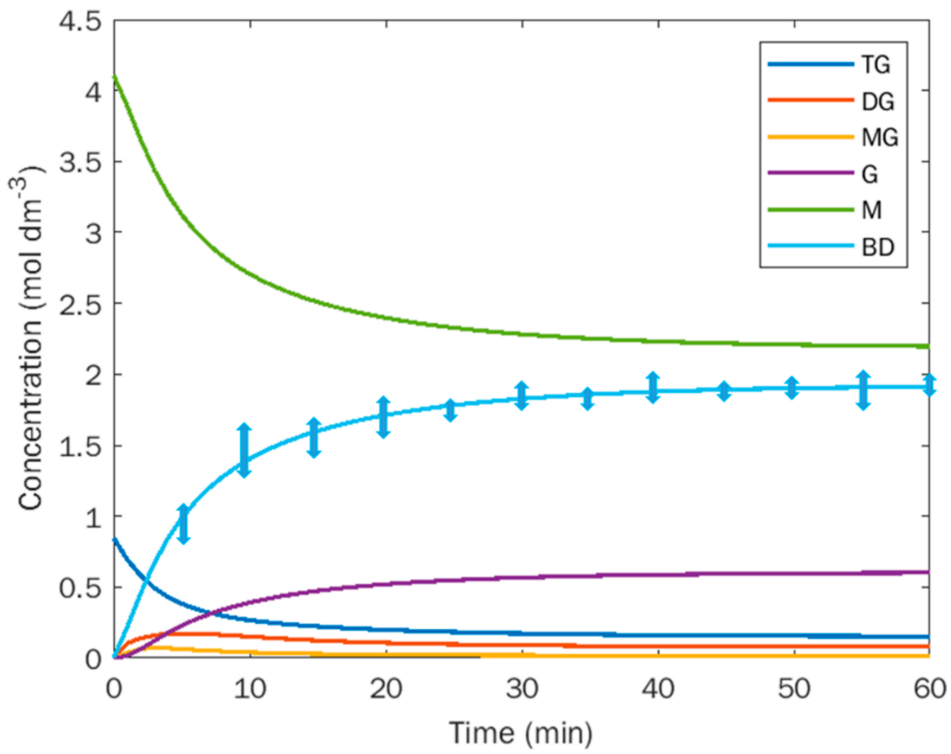

(a)

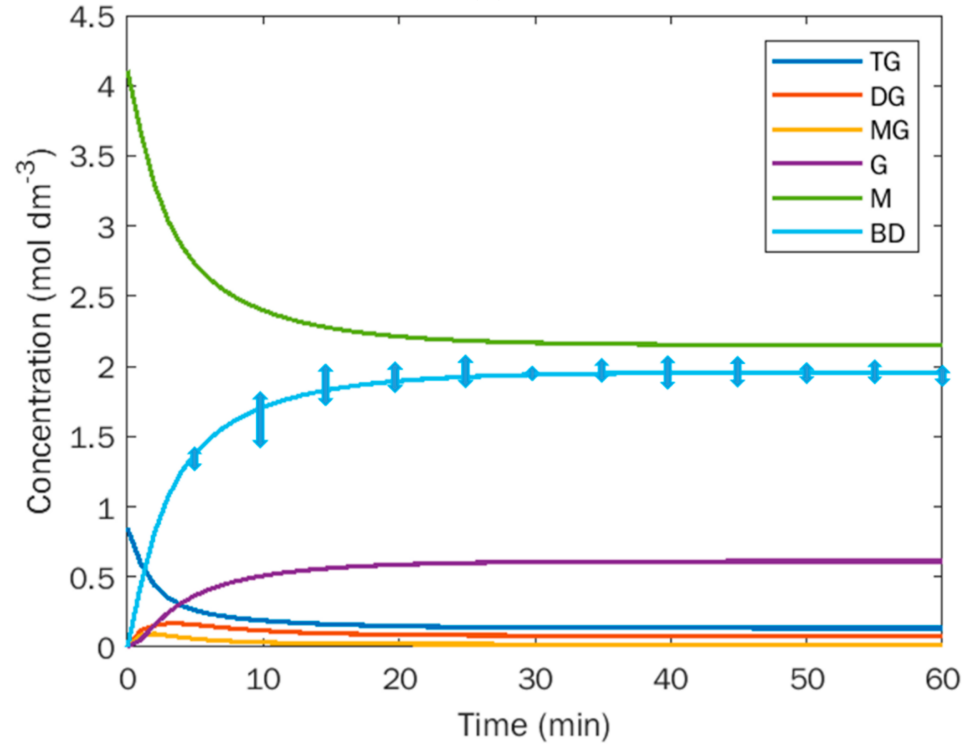

(b)

Figure 6. Simulated transesterification of waste sunflower oil at molar TG:M = 1:5 and catalyst load $=0.6 \% w / w$. Comparison with experimental data at (a) $T=50{ }^{\circ} \mathrm{C}$; (b) $\mathrm{T}=60^{\circ} \mathrm{C}$. 


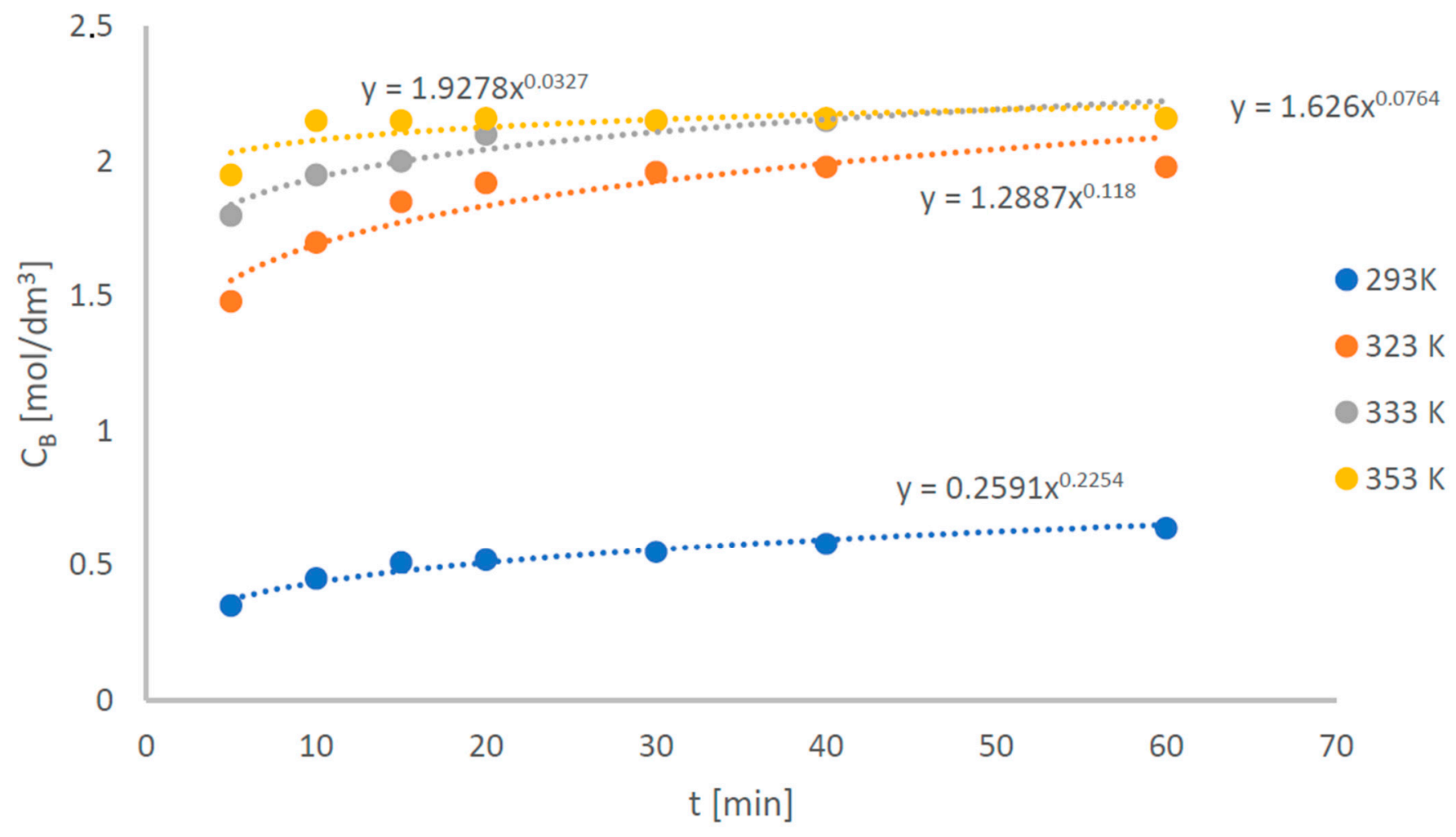

Figure 7. Biodiesel molar concentration curves estimated from experimental data at TG:M=1:5 and different operating temperatures.

Since the hypothesis of irreversible reaction scheme seems to be in agreement with the experimental data at high excess methanol (see both Tables 2 and 3), by neglecting the backward reaction with constant $k_{8}$, the TG molar balance can be written as

$$
\frac{d[\mathrm{TG}]}{d t}=-k_{7}[\mathrm{TG}] \cdot[\mathrm{M}]^{3}
$$

and, for molar TG:M greater than 1:5 (excess methanol), it can be supposed that the reaction rate mainly depends on the oil concentration. Being the remaining methanol concentration almost constant, the molar balance of TG reduces to

$$
\frac{d[\mathrm{TG}]}{d t}=-K[\mathrm{TG}]
$$

with $K=k_{7}[\mathrm{M}]^{3}=$ const.

The analytical derivatives of the fitted biodiesel concentration in time (Figure 7) were calculated and directly used to compute $K$ from the simplified system under the hypothesis of pseudo-first-order reaction rate for all the experimental runs.

The estimated parameter values for the sunflower waste oil with a high catalyst load are $E_{a}=67,348 \mathrm{~J} \mathrm{~mol}^{-1}$ and $k_{0}=2.157 \times 10^{9} \mathrm{~min}^{-1}$. The obtained activation energy is in agreement with [26], in which values in the range 33,600-84,000 $\mathrm{J} \mathrm{mol}^{-1}$ are reported. The kinetics of virgin oils have also been estimated with the same approach and using the pseudo-first-order reaction scheme.

\subsection{Biodiesel Production at the Pilot Scale}

Biodiesel was produced at the pilot scale in discontinuous operating mode. Mean designed residence times of the main unit operations are 3, 50, 120, 50, 15, $120 \mathrm{~min}$, respectively for methanol/ $\mathrm{NaOH}$ mixing, first transesterification, first separation, second transesterification, bubble washing, and second separation. Chosen conditions were at 
$\mathrm{T}=60{ }^{\circ} \mathrm{C}$, molar reactants ratio (TG:M = 1:5) and catalyst load $(1.2 \% w / w)$. Simulations were performed for continuous production using the estimated kinetics to design the correct unit volumes required. In Tables 5 and 6 the operating conditions and results at pilot-scale are summarized.

Table 5. Discontinuous transesterification of waste frying oil, main process data.

\begin{tabular}{|c|c|c|c|c|c|}
\hline $\begin{array}{l}\text { Waste Oil } \\
{[\mathrm{kg}]}\end{array}$ & $\begin{array}{l}\text { Methanol } \\
{[\mathrm{kg}]}\end{array}$ & $\begin{array}{c}\mathrm{NaOH} \\
{[\mathrm{kg}]}\end{array}$ & $\begin{array}{l}\text { Resid. Time } \\
\text { in DSTRs } \\
\text { [min] }\end{array}$ & $\begin{array}{c}\text { Produced } \\
\text { Biodiesel } \\
{[\mathrm{kg}]}\end{array}$ & $\begin{array}{c}\text { Crude } \\
\text { Glycerol } \\
{[\mathrm{kg}]}\end{array}$ \\
\hline 11 & 2 & 0.12 & 50 & $8.8-9$ & $1.7-1.9$ \\
\hline $\begin{array}{c}\text { Wastewater to } \\
\text { Microalgae } \\
\text { [L] }\end{array}$ & $\begin{array}{c}\text { Residual } \\
\text { Glycerol } \\
{\left[\mathrm{g} \mathrm{L}^{-1}\right]}\end{array}$ & $\begin{array}{c}\text { Residual } \\
\text { Methanol } \\
{\left[\mathrm{g} \mathrm{L}^{-1}\right]}\end{array}$ & $\begin{array}{c}\text { Residual NaOH } \\
{\left[\mathrm{g} \mathrm{L}^{-1}\right]}\end{array}$ & $\begin{array}{l}\text { Soaps } \\
{\left[\mathrm{g} \mathrm{L}^{-1}\right]}\end{array}$ & $\begin{array}{c}\text { Salts of } \\
\text { Fatty Acids } \\
{\left[\mathrm{g} \mathrm{L}^{-1}\right]}\end{array}$ \\
\hline 1.2 & $4-12$ & $1-2$ & 3 & 1 & 2 \\
\hline
\end{tabular}

Table 6. Continuous transesterification of waste frying oil, main process data.

\begin{tabular}{|c|c|c|c|c|}
\hline $\begin{array}{l}\text { Inlet Waste Oil } \\
\qquad\left[\mathrm{kg} \mathrm{h}^{-1}\right]\end{array}$ & $\begin{array}{c}\text { Inlet Methanol } \\
{\left[\mathrm{kg} \mathrm{h}^{-1}\right]}\end{array}$ & $\begin{array}{c}\text { Inlet } \mathrm{NaOH} \\
{\left[\mathrm{kg} \mathrm{h}^{-1}\right]}\end{array}$ & $\begin{array}{l}\text { Mean Resid. } \\
\text { Time in CSTRs } \\
\text { [min] }\end{array}$ & $\begin{array}{c}\text { Inlet Oil } \\
\text { Flow Rate } \\
{\left[\mathrm{L} \mathrm{h}^{-1}\right]}\end{array}$ \\
\hline 11 & 2 & 0.12 & 60 & 0.25 \\
\hline $\begin{array}{l}\text { Produced } \\
\text { Biodiesel } \\
{\left[\mathrm{kg} \mathrm{h}^{-1}\right]}\end{array}$ & $\begin{array}{c}\text { Crude } \\
\text { Glycerol } \\
{\left[\mathrm{kg} \mathrm{h}^{-1}\right]}\end{array}$ & $\begin{array}{l}\text { Wastewater to } \\
\text { Microalgae } \\
{\left[\mathrm{L} \mathrm{h}^{-1}\right]}\end{array}$ & $\begin{array}{l}\text { Waste Oil } \\
\text { Conversion } \\
\text { 1st unit }\end{array}$ & $\begin{array}{l}\text { Waste Oil } \\
\text { Conversion } \\
\text { 2nd unit }\end{array}$ \\
\hline $8.6-8.9$ & $1.7-1.8$ & $1-2$ & 0.54 & 0.78 \\
\hline
\end{tabular}

\subsection{Biodiesel Quality Analysis}

Biodiesel is defined by the notation BDxx (Bxx in the USA), where $x x$ indicates the volume percentage of FAME content in the liquid. Pure biodiesel is generally not used as fuel being instead blended with petroleum diesel: common commercial biodiesel blends are BD2, BD5, and BD20 [39]. Biodiesel has to meet defined quality standards before it can be sold as fuel or blending stock. In Europe, the reference is EN 14214 standard, released by the European Committee of Standardization (CEN), while ASTM D6751 is valid in the US. In more detail, the specifications set the required properties as the Lower Heating Value (LHV), kinematic viscosity, density, Cetane number, and some important limits related to the biodiesel production process such as the maximum admitted residual glycerol, catalyst, and alcohol, the absence of free fatty acids (compliance with these characteristics is generally verified by GC-MS) or metals.

Generally, the principal factors influencing the quality of biodiesel obtained by transesterification are the quality of the added reactants and catalyst, the fatty acid composition of the parent vegetable oil or animal fat, and the post-production parameters.

In this work, we also investigated if other possible quality parameters of biodiesel, more than cetane number and LHV, can be defined to underlie differences between the biodiesels produced by virgin and waste sunflower oil.

\subsubsection{FAME Distribution and Cetane Number}

The results of the analysis are summarized in Table 7 , in which the quantities of the most abundant FAMEs inside the biodiesel produced are compared. 
Table 7. Average cetane number $(\mathrm{CN})$ of biodiesel produced from the different oils.

\begin{tabular}{|c|c|c|}
\hline FAME Common Name & $\%$ Total & Average $\mathrm{CN}$ \\
\hline \multicolumn{3}{|c|}{ Waste sunflower oil } \\
\hline Linoleic Acid (di-unsaturated 9-12) & $56.5-56.6 \%$ & $39.0 \pm 0.2$ \\
\hline Oleic Acid (unsaturated) & $28.2-28.4 \%$ & $56.6 \pm 0.2$ \\
\hline Palmitic Acid (saturated) & $7.4-7.6 \%$ & $76.6 \pm 0.3$ \\
\hline Stearic Acid (saturated) & $4.5-4.6 \%$ & $85.9 \pm 0.3$ \\
\hline \multirow{2}{*}{ Tricosanoic Acid (saturated) } & $1.0-1.2 \%$ & $71.6 \pm 0.2$ \\
\hline & Total Cetane number & $47.9 \pm 0.1$ \\
\hline \multicolumn{3}{|c|}{ Virgin sunflower oil } \\
\hline Linoleic Acid (di-unsaturated 9-12) & $58.3-58.5 \%$ & $39.2 \pm 0.1$ \\
\hline Oleic Acid (unsaturated) & $27.1-27.3 \%$ & $56.6 \pm 0.1$ \\
\hline Palmitic Acid (saturated) & $7.2-7.4 \%$ & $76.6 \pm 0.2$ \\
\hline Stearic Acid (saturated) & $4.4-4.6 \%$ & $85.9 \pm 0.3$ \\
\hline \multirow{3}{*}{ Behenic acid (saturated) } & $1.0-1-1 \%$ & $74.1 \pm 0.1$ \\
\hline & Total Cetane number & $47.8 \pm 0.2$ \\
\hline & Olive oil & \\
\hline Oleic Acid (unsaturated) & $80.7-80.9 \%$ & $56.6 \pm 0.2$ \\
\hline Palmitic Acid (saturated) & $12.3-12.4 \%$ & $76.6 \pm 0.2$ \\
\hline \multirow[t]{2}{*}{ Stearic Acid (saturated) } & $3.6-3.8 \%$ & $85.9 \pm 0.3$ \\
\hline & Total Cetane number & $58.4 \pm 0.2$ \\
\hline \multicolumn{3}{|c|}{ Rapeseed oil } \\
\hline Oleic Acid (unsaturated) & $78.4-78.5 \%$ & $56.6 \pm 0.2$ \\
\hline Linoleic Acid (di-unsaturated 9-12) & $8.4-8.6 \%$ & $39.2 \pm 0.3$ \\
\hline Palmitic Acid (saturated) & $5.0-5.2 \%$ & $76.6 \pm 0.3$ \\
\hline Stearic Acid (saturated) & $2.1-2-2 \%$ & $85.9 \pm 0.2$ \\
\hline \multirow[t]{2}{*}{ Eicosanoic acid (unsaturated) } & $1.7-1.8 \%$ & $52.5 \pm 0.2$ \\
\hline & Total Cetane number & $53.4 \pm 0.2$ \\
\hline
\end{tabular}

The percentage of FAME inside biodiesel depends on the initial composition of the oil, and vegetable oils characterized by a low content of residues of unsaturated fatty acids, such as oleic (monounsaturated) and linoleic (poly-unsaturated) acids, ensures ease of combustion and oxidative stability of the produced biodiesel. Moreover, the number and position of double bonds also influence the quality of biodiesel, since they contribute to destabilizing the fatty acid chain by reacting with oxygen forming hydro-peroxides. They attach to the fatty acid chain by degrading it and leading to chain polymerization, forming also insoluble gums.

By looking at Table 7 , it can be observed that the biodiesel produced by the waste and the virgin sunflower oil contains about $85 \%$ of unsaturated fatty acids, and at very similar percentages. Since most of these methyl esters come from linoleic and oleic acid, this validates the hypothesis made for simulations that considers waste oil as pure oleic trioleate. Most probably, it could be also present a small additional quantity of linoleic acid that is not visible because of the peak of oleic acid which almost certainly encompasses it.

Cetane number $(\mathrm{CN})$ is one of the most significant properties to specify the ignition quality of any fuel and, in particular, constitutes the prime indicator for diesel engines since it is related to the ignition delay time [40]. Various standards have been established worldwide for cetane number determination, with standard ISO 5165 by International Organization for Standardization (ISO). Value 100 of cetane number has been assigned to hexadecane $\mathrm{C}_{16} \mathrm{H}_{34}$, to represent the high-quality standard on the cetane scale [41]. Presuming that the $\mathrm{CN}$ of the methyl-esters mixture is a linear combination of the cetane numbers of the single FAMEs [42] the average CNs are calculated from the results of the GC-MS analysis. CN is computed by considering the most abundant FAMEs inside each produced biodiesel with a concentration greater than $1 \%$ weight). Results are reported in Table 7 (see the Supplementary Material, Figures S1-S4 and Tables S1-S9 for the complete 
analysis of biodiesel produced in the chosen operating conditions of $T=60^{\circ} \mathrm{C}, \mathrm{TG}: \mathrm{M}=1: 5$, catalyst load $=0.6 \% w / w)$.

\subsubsection{Lower Heating Value}

The lower heating values found for each biodiesel sample are reported in Table 8 .

Table 8. LHV of the different types of biodiesel.

\begin{tabular}{cc}
\hline Biodiesel Source & LHV $\left[\mathbf{k J ~} \mathbf{~ k g}^{-\mathbf{1}}\right]$ \\
\hline Olive oil & $36,660 \pm 120$ \\
Rapeseed oil & $36,992 \pm 110$ \\
Virgin sunflower oil & $36,079 \pm 110$ \\
Waste sunflower oil & $36,557 \pm 100$ \\
\hline
\end{tabular}

\subsubsection{UV-VIS Analysis}

Biodiesel produced from waste sunflower oil was compared to biodiesel produced from virgin sunflower oil, using the latter as a blank by spectrophotometric analysis. The observation of spectra in the visible length range shows no significant difference between biodiesel from fried sunflower and biodiesel from virgin sunflower oil, as reported in [43]. This fact lets us assume that cooking impurities do not remain inside biodiesel. On the contrary, some important differences are observed by comparing glycerol samples obtained by TE of waste and virgin sunflower oils. In this case, a peak was identified [43] (Appendix A, Figures A1 and A2), pointing out that most cooking residuals and other substances already present in waste oil are mostly dissolved in glycerol. This is probably due to the fact that glycerol is, albeit weakly, a polar compound. This is only a qualitative comparison analysis, the next step being a complete GC-MS analysis of crude glycerol samples.

\subsection{The Recycling of Washing Wastewater}

Waste-oil transesterification leads to the formation of glycerol, unprocessed methanol, catalyst, and small amounts of other chemicals. After bubble washing, crude glycerol is separated and destined for recycling or reuse after purification, while washing wastewater is usually sent to treatment units. In this work, we successfully used the produced wastewater rich in glycerol to feed Chlorella vulgaris, nurtured in photobioreactors in mixotrophic conditions.

At the lab scale, microalgae cultivation added with wastewater allowed to increase the biomass concentration inside the reactors of about $25 \%$ with respect to the control reactors in which microalgae were cultivated only in BBD medium [44]. The kinetic parameters of Chlorella $v$. growth were estimated by the model proposed in [29]:

$$
c(t)=c_{0}+\frac{k_{a}}{1+\frac{k_{a}-c_{0}}{c_{0}} \exp \left(-k_{1} t\right)}
$$

where $k_{1}\left[\mathrm{~d}^{-1}\right]$ represents the specific rate constant, $k_{a}\left[\mathrm{~g} \mathrm{~L}^{-1} \mathrm{~d}^{-1}\right]$ is the maximum increase in the microalgae population, and $c_{0}\left[\mathrm{~g} \mathrm{~L}^{-1}\right]$ is the estimated initial microalgae concentration. In order to reduce errors due to microalgae acclimatization, concentration data collected in the first $24 \mathrm{~h}$ were neglected. Anyway, the experimental growing curve in fedbatch reactors at lab-scale partially contained a short lag-phase; for this reason, the initial concentration $c_{0}$ was estimated with appreciable uncertainty by the non-linear weighted least squares procedure, so as the values of $k_{1}$. As a consequence, the values obtained for the determination coefficients were smaller than those calculated for the airlift reactors.

The obtained growing conditions are summarized in Table 9 for lab and pilot-scale. 
Table 9. Kinetic parameters of growing conditions with wastewater ( $10 \%$ glycerol) and air enriched with $10 \% v / v$ carbon dioxide.

\begin{tabular}{ccccc}
\hline $\begin{array}{c}\text { Operating } \\
\text { Conditions }\end{array}$ & $\begin{array}{c}\boldsymbol{k}_{1} \\
{\left[\mathbf{d}^{-\mathbf{1}}\right]}\end{array}$ & $\begin{array}{c}\boldsymbol{k}_{\boldsymbol{a}} \\
{\left[\mathbf{g ~ L}^{-\mathbf{1}}\right]}\end{array}$ & $\begin{array}{c}\text { Average } \\
\text { Biomass }^{*} \\
{\left[\mathbf{g ~ L}^{-\mathbf{1}} \mathbf{~ d}^{-\mathbf{1}}\right]}\end{array}$ & $\mathbf{R}^{\mathbf{2}}$ \\
\hline $\begin{array}{c}\text { Outdoor, } \\
\text { Fed-batch }\end{array}$ & Min: $0.382 \pm 0.218$ & Min: $1.629 \pm 0.073$ & 233 & 0.742 \\
\hline $\begin{array}{c}\text { Outdoor, } \\
\text { airlift }\end{array}$ & Min: $0.425 \pm 0.253$ & Max: $1.775 \pm 0.082$ & 254 & 0.743 \\
\hline
\end{tabular}

* Biomass is extracted at day 7 in the fed-batch, and cyclically, every 6 days, in the airlift.

Standard deviations reported in Table 9 take into consideration the replicas and the results of the estimation procedure with the proposed model. Since we collected data at different wavelengths, and there is not an optimal wavelength to be used for indirectly measuring concentration when algae are fed with wastewater, we used different calibration curves. Hence, the parameter estimation procedure was carried out many times and with different methods and the results here reported are averaged (a complete set of calibration curves and best fits with Equation (13) for a growing test in fed-batch and outdoor light conditions can be found in the Supplementary Material, Figures S5-S7).

The ranges of the operating parameters were $T=(19-25){ }^{\circ} \mathrm{C}, \mathrm{pH}=(7.5-9.5)$, DOx $=(13-21) \mathrm{mg} \mathrm{L}^{-1}$ and $\mathrm{EC}=(400-820) \mu \mathrm{S}$ (two time-series of one double cultivation test can be found in the Supplementary Material, Figure S8).

Mass balances and best-operating conditions at the pilot-scale are resumed in Table 10.

Table 10. Operating conditions of 12 airlift photobioreactors fed with recycling wastewater and flue-gas.

\begin{tabular}{ccccccc}
\hline $\begin{array}{c}\text { Light } \\
\text { Conditions }\end{array}$ & Regime & $\begin{array}{c}\text { Recycled } \\
\text { Wastewater }\end{array}$ & $\begin{array}{c}\text { Required } \\
\text { Sparging }\end{array}$ & $\begin{array}{c}\text { Recycled } \\
\text { Flue-Gas }\end{array}$ & $\begin{array}{c}\text { Extraction + } \\
\text { Feeding }\end{array}$ & $\begin{array}{c}\text { Brought to } \\
\text { Volume }\end{array}$ \\
\hline $\begin{array}{c}\text { Summer } \\
\text { daylight }\end{array}$ & $\begin{array}{c}\text { Churn flow } \\
\operatorname{Re}_{\text {riser }}=11,000\end{array}$ & $28.8 \mathrm{~L} \mathrm{~d}^{-1}$ & $20 \mathrm{~m}^{3} \mathrm{~h}^{-1} \times 12$ & $90 \mathrm{~m}^{3} \mathrm{~h}^{-1}$ & $\begin{array}{c}\text { Day } 3,6 \\
V=6.2 \mathrm{~L} \times 12\end{array}$ & Day 1, 2, 4, 5 \\
\hline $\begin{array}{c}\text { Winter } \\
\text { daylight }\end{array}$ & $\begin{array}{c}\text { Churn flow } \\
\mathrm{Re}_{\text {riser }}=10,300\end{array}$ & $28.8 \mathrm{~L} \mathrm{~d}^{-1}$ & $20 \mathrm{~m}^{3} \mathrm{~h}^{-1} \times 12$ & $90 \mathrm{~m}^{3} \mathrm{~h}^{-1}$ & $\begin{array}{c}\text { Day } 6 \\
V=9.1 \mathrm{~L} \times 12\end{array}$ & Day $1,2,3,4,5$ \\
\hline $\begin{array}{c}\text { Night } \\
\text { conditions }\end{array}$ & $\begin{array}{c}\text { Bubble flow } \\
\mathrm{Re}_{\text {riser }}=5200\end{array}$ & $28.8 \mathrm{~L} \mathrm{~d}^{-1}$ & $3-4 \mathrm{~m}^{3} \mathrm{~h}^{-1} \times 12$ air & Storage tank & - \\
\hline
\end{tabular}

\subsection{The Potential of Glycerol, a By-Product of the Production of Bioesters}

The weight composition of the produced crude glycerol is glycerol (55-60\%), methanol $(25-30 \%)$, water $(8 \%)$, fatty acids esters $(3 \%)$, salts of fatty acids $(2 \% w / w)$, and sodium chloride $(2 \%)$.

The simplest method of valorizing crude glycerol consists of its combustion, which does not require any purification. The LHV of glycerol is about two times lower than that of fossil fuels, and it is comparable to the heat of combustion of most types of biomass. Due to the high content of water in crude glycerol obtained as a by-product of oil transesterification, often a co-combustion of glycerol with other liquid fuels is performed in special burners [45]. Moreover, pyrolysis and gasification are used, and they are usually carried out at $650-800{ }^{\circ} \mathrm{C}$ under atmospheric pressure [46-48]. Steam reforming [49] is another valuable process to produce hydrogen from crude glycerol, and the most effective catalysts used are silica or $\left(\mathrm{Al}_{2} \mathrm{O}_{3}\right)$-supported nickel, cobalt, nickel/copper, platinum, and other metals such as Rh, Ir, Ru, Zr, Ce, La [50].

The authors [21,43] proposed to use crude glycerol in co-gasification with biomass, in the form of solid waste pellets, to heighten the LHV and improve the quality of the syngas. In this perspective, a pursuable possibility consists in designing a small-scale energy-generating plant hinging on an internal combustion engine running on biodiesel 
coupled with a gasifier exploiting the biomass impregnated with glycerol. In this sense, some experimental tests were performed by comparing the syngas produced from wood chips, pellets, with that originating from the glycerol-imbued biowaste [43], confirming the increase of the combustion quality due to the addition of crude glycerol to the organic wastes, manifested in both the increase of the flues gas temperature, gauged at the end of the combustion zone, and in a better flue gas chemical composition. Nevertheless, it would be advisable to carry out further testing in order to optimize the gasification process.

On a broader note, additional ongoing studies are focused on enlarging the concept of the proposed tending-to-zero-waste TE process. In particular, the authors are analyzing photocatalysis and bioconversion to directly produce hydrogen.

\section{Discussion}

\subsection{Kinetics of Transesterification}

The kinetics of biodiesel production from waste sunflower oil was deeply investigated by adopting three different reaction schemes. The first scheme considered a three reversible second-order reaction network, the second scheme took into consideration one fourthorder reversible reaction while the third scheme was based on one pseudo-first-order irreversible reaction. We computed the activation energies and the pre-exponential factors for the first scheme from kinetic data reported in [36] that seem to better describe our experimental data among the possible kinetics found in the literature. Furthermore, we estimated the kinetic parameters from our experimental data, using both the second and the third reaction schemes.

Regarding the waste sunflower oil, the obtained values with the fourth-order reversible reaction are $E_{a, \text { direct }}=35,661 \mathrm{~J} \mathrm{~mol}^{-1}, E_{a, \text { reverse }}=72,989 \mathrm{~J} \mathrm{~mol}^{-1}, k_{0, \text { direct }}=9.7708\left[\mathrm{dm}^{3} \mathrm{~mol}^{-1}\right]^{3} \mathrm{~min}^{-1}$, and $k_{0 \text {,reverse }}=24,810\left[\mathrm{dm}^{3} \mathrm{~mol}^{-1}\right]^{3} \mathrm{~min}^{-1}$.

The obtained values for the pseudo-first-order transesterification of waste sunflower oil are $E_{a}=67,348 \mathrm{~J} \mathrm{~mol}^{-1} \mathrm{~K}^{-1}$ and $k_{0}=2.157 \times 10^{9} \mathrm{~min}^{-1}$, in agreement with [26], in which values in the range $33,600-84,000 \mathrm{~J} \mathrm{~mol}^{-1} \mathrm{~K}^{-1}$ are reported, in agreement with [51] where values of $E_{a}=79,000 \mathrm{~J} \mathrm{~mol}^{-1} \mathrm{~K}^{-1}$ and $k_{0}=2.98 \times 10^{10} \mathrm{~min}^{-1}$ are found for soybean waste oil and a catalyst based on snail shell.

By comparing kinetics estimated for the different oils, the most important obtained results can be summarized as follows:

1. Similar yields in biodiesel are obtained for the waste and the virgin sunflower oil using for the former an almost doubled quantity of sodium hydroxide catalyst; the probable reason being that in the exhaust oil more free fatty acids are present;

2. A pseudo-first-order reaction scheme can be adopted to model the transesterification reaction of different kinds of oils in the chosen temperature ranges, only paying attention that the system is reaction controlled for almost all the reaction time. This condition is assured at $\operatorname{Re}=8000$ at lab-scale;

3. The values of the activation energy estimated from the experimental data do not differ a lot by changing the type of oil (sunflower, rapeseed, and olive oil) and this is in agreement with the literature, where similar values of activation energy are found for different waste/virgin oils. Conversely, the estimated values of the pre-exponential factor highly depend on oil type and operating conditions.

\subsection{Quality of Biodiesel}

Since glycerol and alcohol excess pose major fuel contamination issues, washing of biodiesel was carried out by bubble washing before separation.

We computed the cetane number from GC-MS analysis. Generally, for values as high as 55 to 60, an improvement in biodiesel emissions is witnessed, although exceeding that threshold showed only a slight improvement. The cetane number of biodiesel from olive oil, which amounted to $58.4 \pm 0.2$, is then inside the optimal range, while that of biodiesel from rapeseed oil is reasonably near (53.4). EN 14214 prescribes a minimum of 51, while ASTM D975 (American Standard Specification for Diesel Fuel Oils) set the minimum value 
of cetane number at 47; this means that biodiesel produced from both new (47.8 \pm 0.2$)$ and used $(47.9 \pm 0.2)$ sunflower oil does not conform to the European standards but only for the American ones. The dissimilarities in cetane numbers are caused by the chain length (cetane number increases with it), the number and location of double bonds (cetane number is inversely proportional to the number of double bonds), and changes with various locations of the carbonyl group. Moreover, through GC investigations potential instability issues have emerged: peaks on chromatograms of every biodiesel sample were identified in correspondence with the retention time of the oleic acid and possibly linoleic acid, and the degree of saturation of the fatty acid chains tends to be correlated with stability.

The energy content of biodiesel was measured by LHV. Generally, the fuel consumption is proportional to the volumetric energy density of the fuel based on the lower heating value. In order to provide a comparison, petroleum diesel contains about 30,473 [ $\left.\mathrm{kJ} \mathrm{kg}^{-1}\right]$, while biodiesel accounts for about $27,177\left[\mathrm{~kJ} \mathrm{~kg}^{-1}\right]$ [52]. The results of the tested biodiesel samples are then excellent since they all surpass $36,000\left[\mathrm{~kJ} \mathrm{~kg}^{-1}\right]$.

\subsection{Microalgae Using Washing Wastewater}

Even if the washing wastewater contained residuals of methanol, catalyst and salts of fatty acids (Table 5), as well as glycerol, the experiments confirmed that microalgal strain Chlorella $v$. has a good capability of using this wastewater to grow in outdoor and in mixotrophic conditions. The experiments confirmed interesting results in terms of average biomass production, ranging from 233 to $266 \mathrm{~g} \mathrm{~L}^{-1} \mathrm{~d}^{-1}$. Moreover, the yields obtained are about $25 \%$ greater than those obtained with the same strain in control conditions. The first results about the percentage of lipids extracted are in agreement with the literature. Finally, the chemical analysis of the wastewater in exit confirm that glycerol conversion by microalgae is in the range $60-80 \%$.

\subsection{Feasibility of the Coupled Process}

The energetic performance of the $\mathrm{NaOH}$-activated TE process can be estimated by computing the energy equivalents of the reactants and products and by adding the direct energy consumption. A net energy production of $13.70 \mathrm{MJ} \mathrm{L}^{-1}$, of which about $78 \%$ is renewable, was calculated in [53] by considering a value of $37.25 \mathrm{MJ} \mathrm{L}^{-1}$ for the produced biodiesel (in agreement with our LHW $=36,600 \mathrm{MJ} \mathrm{kg}^{-1}$ ). Usually, the cost of wastewater treatment is not considered in these calculations, so the use of washing wastewater as a feed to microalgae can increase the global techno-economic performance of this biodiesel production, even if a classical catalyst as $\mathrm{NaOH}$ is used.

Calculated absolute yields at TG:M $=1: 5$, cat $=1.2 \% w / w$, residence time $\left(t_{R}\right)=60$ min and $T=60{ }^{\circ} \mathrm{C}$ varied from $77 \pm 3 \%$ and $82 \pm 2 \%$. They are in agreement with the results obtained in previous works even if lower, as expected, than those obtained with higher TG:M ratios, as reported in [54] where for TG:M $=1: 12$, cat $=2 \% w / w, t_{R}=70$ min and $T=55{ }^{\circ} \mathrm{C}$ a yield of $94 \%$ is obtained. In [55], $\mathrm{NaOH}$ catalyst was used for the TE of waste sunflower oil added with oil extracted from microalgae and a calculated yield of $95 \%$ in the optimal conditions of TG:M $=4: 6 v / v, t_{R}=130 \mathrm{~min}$ and $T=50{ }^{\circ} \mathrm{C}$ is reported. Other studies show yields greater than $90 \%$ only with very high TG:M ratios and high residence times. Many research activities have recently been devoted to the development of heterogeneous catalysts, as acid-supported porous or metal-supported polymers. In [56] a maximum yield of $95 \%$ is reached with TG:M $=1: 15,4 \% w / w$ catalyst, $t_{R}=240 \mathrm{~min}$ and $T=120{ }^{\circ} \mathrm{C}$ and using a MgAl-LDH-geopolymer. The operating conditions proposed in this work with yields reaching $82 \%$ are in our opinion the correct ones for the scale-up of the process to a continuous production. Higher yields, obtained at laboratory scale with residence times of more than two hours and high TG:M ratios could not be convenient for integrating this process into industrial scale biorefineries, since the increase of $t_{R}$ needs high reactor volumes (with possible mixing problems) or lower flow rates so decreasing production rate, and the increase of TG:M requires higher costs for methanol recycling. 


\section{Conclusions}

In this work we proposed to improve the feasibility of a second-generation biodiesel production process by coupling it with microalgae cultivation. The transesterification of waste sunflower oil with methanol and $\mathrm{NaOH}$ as catalyst is analyzed. This TE process needs a significant washing step since appreciable quantities of soaps can be formed, but if the wastewater in exit from the washing unit, rich in glycerol, is used as a feed to the microalgae, it becomes very interesting at industrial scale. At TG:M $=1: 5 w / w, T=50-60{ }^{\circ} \mathrm{C}$, catalyst load $=1.2 \% w / w$ and residence time $=60 \mathrm{~min}$, the yield at the pilot scale reached $82 \%$. Three different kinetic schemes were investigated, and the study showed that a pseudo-first order scheme well represents the reaction mechanism at the chosen conditions. Results were also reported about growing tests of Chlorella vulgaris cultivated in outdoor and in mixotrophic conditions, fed with washing wastewater. An increase of $25 \%$ in microalgae production was obtained. Finally, the mass balance of the designed continuous pilot-scale coupled process was reported, showing that a cyclical feeding can be designed in order to recycle all the washing wastewater produced.

Supplementary Materials: The following are available online at https://www.mdpi.com/article/ 10.3390/su14010273/s1, Table S1: GC device technical conditions and specifics; Figure S1: GC of biodiesel from virgin olive oil $\left(T=60^{\circ} \mathrm{C}\right.$, molar TG:M $=1: 5$, cat $\left.=0.6 w / w\right)$; Table S2: GC data of biodiesel from virgin olive oil $\left(T=60^{\circ} \mathrm{C}\right.$, molar TG:M $=1: 5$, cat $\left.=0.6 w / w\right)$; Table S3: FAME in biodiesel produced from virgin olive oil $\left(T=60^{\circ} \mathrm{C}\right.$, molar TG:M $=1: 5$, cat $\left.=0.6 w / w\right)$; Figure S2: GC of biodiesel from virgin rapeseed oil $\left(T=60^{\circ} \mathrm{C}\right.$, molar TG:M $=1: 5$, cat $\left.=0.6 w / w\right)$; Table S4: GC data of biodiesel from virgin rapeseed oil $\left(T=60^{\circ} \mathrm{C}\right.$, molar TG:M $=1: 5$, cat $\left.=0.6 \mathrm{w} / \mathrm{w}\right)$; Table S5: FAMEs in biodiesel produced from virgin rapeseed oil $\left(T=60^{\circ} \mathrm{C}\right.$, molar TG:M $=1: 5$, cat $\left.=0.6 w / w\right)$; Figure S3: GC of biodiesel from virgin sunflower oil $\left(T=60^{\circ} \mathrm{C}\right.$, molar TG:M $=1: 5$, cat $\left.=0.6 w / w\right)$; Table S6: GC data of biodiesel from virgin sunflower oil $\left(T=60^{\circ} \mathrm{C}\right.$, molar TG:M $=1: 5$, cat $\left.=0.6 w / w\right)$; Table S7: FAMEs in biodiesel produced from virgin sunflower oil $\left(T=60^{\circ} \mathrm{C}\right.$, molar TG:M $=1: 5$, cat $\left.=0.6 \mathrm{w} / \mathrm{w}\right)$; Figure S4: GC of biodiesel from waste sunflower oil $\left(T=60^{\circ} \mathrm{C}\right.$, molar TG:M $=1: 5$, cat $=1.2 w / w$ repl. 1/3); Table S8: GC data of biodiesel from waste sunflower oil $\left(T=60^{\circ} \mathrm{C}\right.$, molar TG:M $=1: 5$, cat $=1.2 w / w$, repl. 1/3); Table S9: FAMEs in biodiesel produced from waste sunflower oil $\left(T=60^{\circ} \mathrm{C}\right.$, molar TG:M = 1:5, cat $=1.2 w / w$, repl. 1/3); Figure S5: Calibration curves at (a) $430 \mathrm{~nm}$; (b) $480 \mathrm{~nm}$; (c) $650 \mathrm{~nm}$; (d) $680 \mathrm{~nm}$; $€$ overall, at steps of $10 \mathrm{~nm}$; Figure S6: Estimated growth curves at different wavelengths (each own calibration curve), (a) $430 \mathrm{~nm}$, (b) $480 \mathrm{~nm}$, (c) $650 \mathrm{~nm}$, (d) $680 \mathrm{~nm}$; Figure S7: Estimated growth curves at different wavelengths (using the overall calibration curve), (a) $430 \mathrm{~nm}$, (b) $480 \mathrm{~nm}$, (c) $650 \mathrm{~nm}$, (d) $680 €$ (e) global spectrum; Figure S8: Online measured parameters during microalgae cultivation.

Author Contributions: Conceptualization, O.P.; methodology, O.P. and M.N.; software, M.N.; validation, O.P. and M.N.; formal analysis, O.P. and M.N.; investigation, O.P. and M.N.; resources, O.P.; writing—original draft preparation, O.P. and M.N.; writing—review and editing, O.P. and M.N. All authors have read and agreed to the published version of the manuscript.

Funding: This research received no external funding.

Institutional Review Board Statement: Not applicable.

Informed Consent Statement: Not applicable.

Data Availability Statement: Not applicable.

Acknowledgments: The authors wish to thank Francesca Fissore and Antonio Como for their help during the experimental campaigns carried out in Savona Campus, University of Genoa.

Conflicts of Interest: The authors declare no conflict of interest. 


\section{Appendix A}

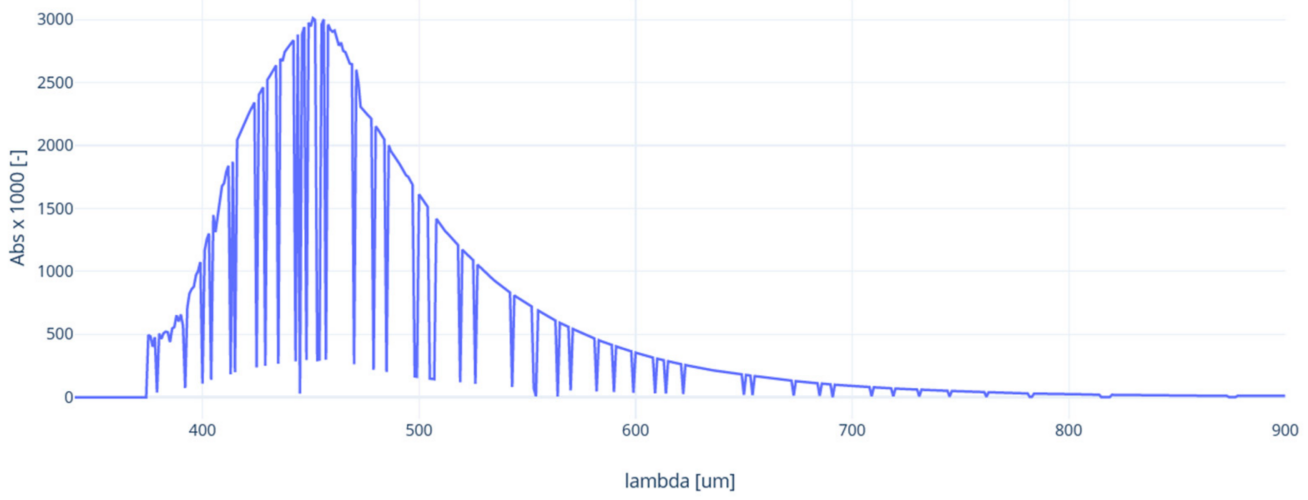

Figure A1. Spectrum of glycerol obtained by transesterification of waste sunflower oil, using glycerol from virgin sunflower oil as a blank.

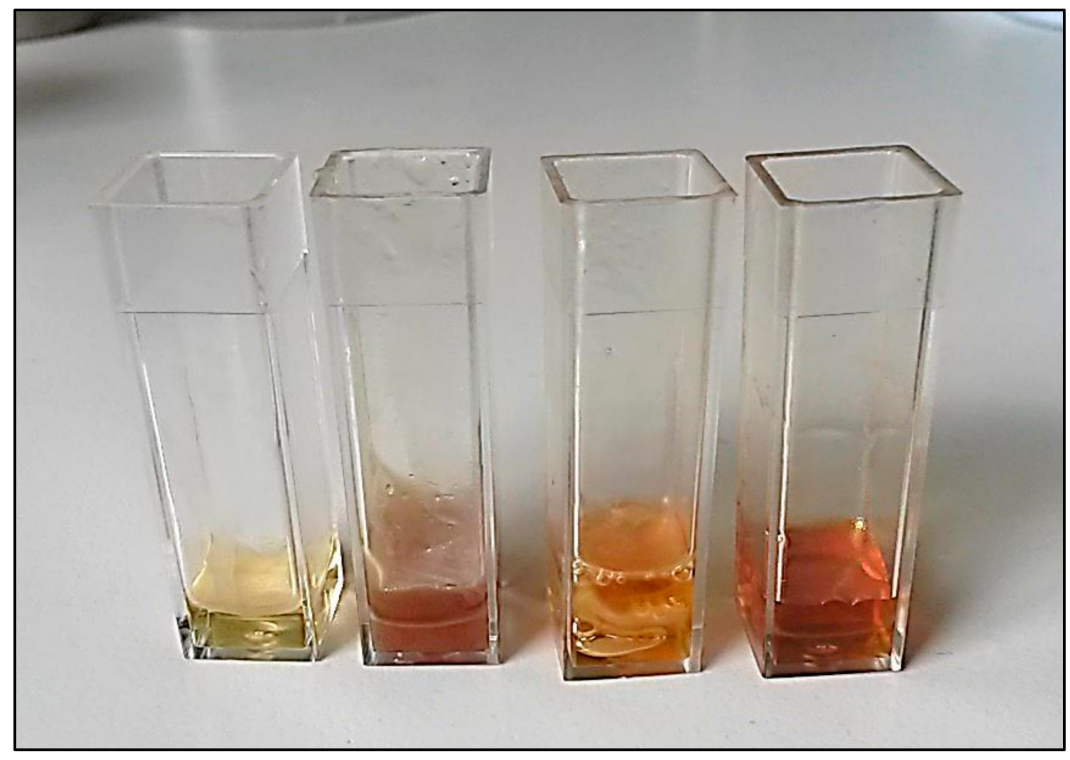

Figure A2. Glycerol samples obtained (starting from left to right) from olive oil, rapeseed oil, virgin sunflower oil, and waste sunflower oil.

\section{References}

1. Ritchie, H.; Roser, M. Energy: Fossil Fuels. Available online: https:/ / ourworldindata.org/fossil-fuels (accessed on 1 November 2021).

2. Bardi, U. Peak Oil, 20 Years Later: Failed Prediction or Useful Insight? Energy Res. Soc. Sci. 2019, 48, 257-261. [CrossRef]

3. Welsby, D.; Price, J.; Pye, S.; Ekins, P. Unextractable Fossil Fuels in a $1.5^{\circ} \mathrm{C}$ World. Nature 2021, 597, 230-234. [CrossRef]

4. Varone, A.; Ferrari, M. Power to Liquid and Power to Gas: An Option for the German Energiewende. Renew. Sustain. Energy Rev. 2015, 45, 207-218. [CrossRef]

5. Araújo, K.; Mahajan, D.; Kerr, R.; da Silva, M. Global Biofuels at the Crossroads: An Overview of Technical, Policy, and Investment Complexities in the Sustainability of Biofuel Development. Agriculture 2017, 7, 32. [CrossRef]

6. Anastopoulos, G.; Zannikou, Y.; Stournas, S.; Kalligeros, S. Transesterification of Vegetable Oils with Ethanol and Characterization of the Key Fuel Properties of Ethyl Esters. Energies 2009, 2, 362-376. [CrossRef]

7. Ferella, F.; Mazziotti Di Celso, G.; De Michelis, I.; Stanisci, V.; Vegliò, F. Optimization of the Transesterification Reaction in Biodiesel Production. Fuel 2010, 89, 36-42. [CrossRef]

8. Ma, F.; Clements, L.D.; Hanna, M.A. Biodiesel Fuel from Animal Fat. Ancillary Studies on Transesterification of Beef Tallow. Ind. Eng. Chem. Res. 1998, 37, 3768-3771. [CrossRef]

9. Janaun, J.; Ellis, N. Perspectives on Biodiesel as a Sustainable Fuel. Renew. Sustain. Energy Rev. 2010, 14, 1312-1320. [CrossRef]

10. Pasqualino, J.C.; Montané, D.; Salvadó, J. Synergic Effects of Biodiesel in the Biodegradability of Fossil-Derived Fuels. Biomass Bioenergy 2006, 30, 874-879. [CrossRef] 
11. Sharma, Y.C.; Singh, B.; Upadhyay, S.N. Advancements in Development and Characterization of Biodiesel: A Review. Fuel 2008, 87, 2355-2373. [CrossRef]

12. Labeckas, G.; Slavinskas, S. The Effect of Rapeseed Oil Methyl Ester on Direct Injection Diesel Engine Performance and Exhaust Emissions. Energy Convers. Manag. 2006, 47, 1954-1967. [CrossRef]

13. Naylor, R.L.; Higgins, M.M. The Political Economy of Biodiesel in an Era of Low Oil Prices. Renew. Sustain. Energy Rev. 2017, 77, 695-705. [CrossRef]

14. Lamers, P.; Hamelinck, C.; Junginger, M.; Faaij, A. International Bioenergy Trade-A Review of Past Developments in the Liquid Biofuel Market. Renew. Sustain. Energy Rev. 2011, 15, 2655-2676. [CrossRef]

15. Smyth, S.J.; Lubieniechi, S. The Food Versus Feed/Fuel Debate. In Plant Bioproducts; Chen, G., Weselake, R., Singer, S., Eds.; Springer: New York, NY, USA, 2018; pp. 219-244. ISBN 978-1-4939-8616-3.

16. Ayoub, M.; Abdullah, A.Z. Critical Review on the Current Scenario and Significance of Crude Glycerol Resulting from Biodiesel Industry towards More Sustainable Renewable Energy Industry. Renew. Sustain. Energy Rev. 2012, 16, 2671-2686. [CrossRef]

17. Ramesh kumar, V.; Narendrakumar, G.; Thyagarajan, R.; Melchias, G. A Comparative Analysis of Biodiesel Production and Its Properties from Leptolyngbya Sp. BI-107 and Chlorella Vulgaris under Heat Shock Stress. Biocatal. Agric. Biotechnol. 2018, 16, 502-506. [CrossRef]

18. Perez-Garcia, O.; Escalante, F.M.E.; de-Bashan, L.E.; Bashan, Y. Heterotrophic Cultures of Microalgae: Metabolism and Potential Products. Water Res. 2011, 45, 11-36. [CrossRef] [PubMed]

19. Ma, X.; Zheng, H.; Addy, M.; Anderson, E.; Liu, Y.; Chen, P.; Ruan, R. Cultivation of Chlorella Vulgaris in Wastewater with Waste Glycerol: Strategies for Improving Nutrients Removal and Enhancing Lipid Production. Bioresour. Technol. 2016, 207, 252-261. [CrossRef]

20. Choi, H.-J.; Yu, S.-W. Influence of Crude Glycerol on the Biomass and Lipid Content of Microalgae. Biotechnol. Biotechnol. Equip. 2015, 29, 506-513. [CrossRef]

21. Paladino, O.; Neviani, M. Airlift Photo-Bioreactors for Chlorella Vulgaris Cultivation in Closed-Loop Zero Waste Biorefineries. Biomass Bioenergy 2021, 144, 105926. [CrossRef]

22. Otera, J. Transesterification. Chem. Rev. 1993, 93, 1449-1470. [CrossRef]

23. Wright, H.J.; Segur, J.B.; Clark, H.V.; Coburn, S.K.; Langdon, E.E.; DuPuis, R.N. A Report on Ester Interchange. Oil Soap 1944, 21, 145-148. [CrossRef]

24. Freedman, B.; Butterfield, R.O.; Pryde, E.H. Transesterification Kinetics of Soybean Oil 1. J. Am. Oil Chem. Soc. 1986, 63, 1375-1380. [CrossRef]

25. Schuchardt, U.; Sercheli, R.; Vargas, R.M. Transesterification of Vegetable Oils: A Review. J. Braz. Chem. Soc. 1998, 9, 199-210. [CrossRef]

26. Freedman, B.; Pryde, E.H.; Mounts, T.L. Variables Affecting the Yields of Fatty Esters from Transesterified Vegetable Oils. J. Am. Oil Chem. Soc. 1984, 61, 1638-1643. [CrossRef]

27. Schwab, A.W.; Bagby, M.O.; Freedman, B. Preparation and Properties of Diesel Fuels from Vegetable Oils. Fuel 1987, 66, 1372-1378. [CrossRef]

28. Aksoy, H.A.; Becerik, I.; Karaosmanoğlu, F.; Yatmaz, H.C.; Civelekoğlu, H. Utilization Prospects of Turkish Raisin Seed Oil as an Alternative Engine Fuel. Fuel 1990, 69, 600-603. [CrossRef]

29. Filip, V.; Zajic, J.; Smidrkal, J. Methanolysis of Rapeseed Oil Triglycerides. Rev. Fr. Corps Gras 1992, 39, 91-94.

30. Duran, E.A.; Tinoco, R.; Pérez, A.; Berrones, R.; Eapen, D.; Sebastián, P.J. A Conparative Study of Biodiesel Purification with Magnesium Silicate and Water. J. New Mater. Electrochem. Syst. 2014, 17, 105-111. [CrossRef]

31. Saengprachum, N.; Pengprecha, S.; Poothongkam, J. Glycerine Removal in Biodiesel Purification Process by Adsorbent from Rice Husk. Int. J. Sci. Eng. Technol. 2013, 2, 474-478.

32. Sims, B. Finding the Right Purification Approach. Trends in Biodiesel Washing and Polishing. Available online: http://www. biodieselmagazine.com/articles/7661/ finding-the-right-purification-approach (accessed on 7 July 2021).

33. Homer, I.; Hunter, E. Comparison of Different Artisan Methods to Obtaining Biodiesel. Int. J. Sci. Environ. Technol. 2014, 3, 33-47.

34. Paladino, O.; Fissore, F.; Neviani, M. A Low-Cost Monitoring System and Operating Database for Quality Control in Small Food Processing Industry. J. Sens. Actuator Netw. 2019, 8, 52. [CrossRef]

35. Paladino, O.; Neviani, M. Scale-up of Photo-Bioreactors for Microalgae Cultivation by $\pi$-Theorem. Biochem. Eng. J. 2020, 153, 107398. [CrossRef]

36. Noureddini, H.; Zhu, D. Kinetics of Transesterification of Soybean Oil. J. Am. Oil Chem. Soc. 1997, 74, 1457-1463. [CrossRef]

37. Reyero, I.; Arzamendi, G.; Zabala, S.; Gandía, L.M. Kinetics of the NaOH-Catalyzed Transesterification of Sunflower Oil with Ethanol to Produce Biodiesel. Fuel Process. Technol. 2015, 129, 147-155. [CrossRef]

38. Vicente, G.; Martínez, M.; Aracil, J.; Esteban, A. Kinetics of Sunflower Oil Methanolysis. Ind. Eng. Chem. Res. 2005, 44, 5447-5454. [CrossRef]

39. McCurry, J.D.; Wang, C.-X.; Zone, W.F. Analysis of Glycerin and Glycerides in Biodiesel (B100) Using ASTM D6584 and EN14105. 2007. Available online: citeseerx.ist.psu.edu/viewdoc/download?doi=10.1.1.468.9267\&rep=rep1\&type=pdf (accessed on 1 November 2021).

40. Gopinath, A.; Puhan, S.; Nagarajan, G. Effect of Biodiesel Structural Configuration on Its Ignition Quality. Int. J. Energy Environ. 2010, 1, 295-306. 
41. Knothe, G. Dependence of Biodiesel Fuel Properties on the Structure of Fatty Acid Alkyl Esters. Fuel Process. Technol. 2005, 86, 1059-1070. [CrossRef]

42. Murphy, M.; Taylor, J.; McCormick, R. Compendium of Experimental Cetane Number Data. In National Renewable Energy Laboratory; US Department of Energy: Columbus, OH, USA, 2004; NREL/SR-540-36805.

43. Paladino, O.; Neviani, M. A Closed Loop Biowaste to Biofuel Integrated Process Fed with Waste Frying Oil, Organic Waste and Algal Biomass: Feasibility at Pilot Scale. Renew. Energy 2018, 124, 61-74. [CrossRef]

44. Bischoff, H.W.; Bold, H.C. Phycological Studies IV. Some Soil Algae from Enchanted Rock and Related Algal Species; University of Texas Publication N. 6318: Austin, TX, USA, 1963.

45. Stelmachowski, M. Utilization of Glycerol, a by-Product of the Transestrification Process of Vegetable Oils: A Review. Ecol. Chem. Eng. S 2011, 18, 9-30.

46. Valliyappan, T.; Bakhshi, N.N.; Dalai, A.K. Pyrolysis of Glycerol for the Production of Hydrogen or Syn Gas. Bioresour. Technol. 2008, 99, 4476-4483. [CrossRef]

47. Chaudhari, S.; Bhakshi, N. Steam Gasification of Chars and Bio-Oil; Report to Bioenergy Development Program Renewable Energy Branch; Energy, Mines and Resources: Ottawa, ON, Canada, 2002; pp. 396-436.

48. Fernández, Y.; Arenillas, A.; Díez, M.A.; Pis, J.J.; Menéndez, J.A. Pyrolysis of Glycerol over Activated Carbons for Syngas Production. J. Anal. Appl. Pyrolysis 2009, 84, 145-150. [CrossRef]

49. Douette, A.M.D.; Turn, S.Q.; Wang, W.; Keffer, V.I. Experimental Investigation of Hydrogen Production from Glycerin Reforming. Energy Fuels 2007, 21, 3499-3504. [CrossRef]

50. Adhikari, S.; Fernando, S.; Gwaltney, S.R.; Filip To, S.D.; Mark Bricka, R.; Steele, P.H.; Haryanto, A. A Thermodynamic Analysis of Hydrogen Production by Steam Reforming of Glycerol. Int. J. Hydrogen Energy 2007, 32, 2875-2880. [CrossRef]

51. Birla, A.; Singh, B.; Upadhyay, S.N.; Sharma, Y.C. Kinetics Studies of Synthesis of Biodiesel from Waste Frying Oil Using a Heterogeneous Catalyst Derived from Snail Shell. Bioresour. Technol. 2012, 106, 95-100. [CrossRef] [PubMed]

52. Bajpai, D.; Tyagi, V.K. Biodiesel: Source, Production, Composition, Properties and Its Benefits. J. Oleo Sci. 2006, 55, 487-502. [CrossRef]

53. John, M.; Abdullah, M.O.; Hua, T.Y.; Nolasco-Hipólito, C. Techno-Economical and Energy Analysis of Sunflower Oil Biodiesel Synthesis Assisted with Waste Ginger Leaves Derived Catalysts. Renew. Energy 2021, 168, 815-828. [CrossRef]

54. Naik, B.D.; Meivelu, U. Experimental Studies on Sodium Methoxide Supported Bentonite Catalyst for Biodiesel Preparation from Waste Sunflower Oil. Environ. Prog. Sustain. Energy 2020, 39, e13390. [CrossRef]

55. Fazil Khan, M.; Garg, A.; Jain, S.; Dwivedi, G.; Nath Verma, T. Optimization of Low-Temperature Transesterification of Low FFA Blend of Sunflower Oil and Algae Oil. Fuel 2020, 279, 118459. [CrossRef]

56. Sayed, M.R.; Abukhadra, M.R.; Abdelkader Ahmed, S.; Shaban, M.; Javed, U.; Betiha, M.A.; Shim, J.-J.; Rabie, A.M. Synthesis of Advanced MgAl-LDH Based Geopolymer as a Potential Catalyst in the Conversion of Waste Sunflower Oil into Biodiesel: Response Surface Studies. Fuel 2020, 282, 118865. [CrossRef] 